\title{
Impact of a trimodal prehabilitation program on functional recovery after colorectal cancer surgery: a pilot study
}

\author{
Chao Li \\ Master of Science \\ Department of Surgical Research \\ McGill University \\ Montréal, Québec, Canada
}

December 2012

Submitted to McGill University in partial fulfillment of the requirements of the degree of Master's of Science in Experimental Surgery

(C) 2012 Chao Li 


\section{TABLE OF CONTENTS}

LIST OF TABLES . . . . . . . . . . . . . . . . . . iv

LIST OF FIGURES . . . . . . . . . . . . . . . . . . . . . v v

LIST OF ABBREVIATIONS ..................... . . vi

CONTRIBUTION OF AUTHORS .................. vii

ACKNOWLEDGEMENTS .............................. vii

ABSTRACT ............................ ix

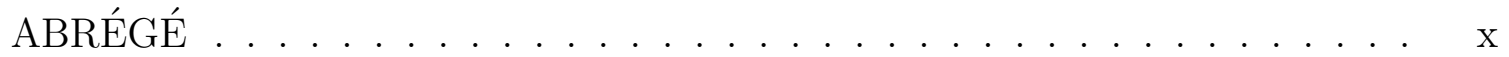

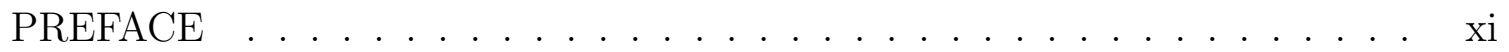

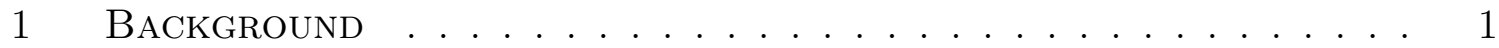

1.1 Colorectal Cancer . . . . . . . . . . . . . . . . . 1

1.1.1 Epidemiology . . . . . . . . . . . . . . . 1

1.1.2 Pathophysiology and Clinical Presentation ........ . 2

1.1.3 Treatment Strategies . . . . . . . . . . . . . . 4

1.2 Recovery after Surgery . . . . . . . . . . . . . . . 5

1.2.1 Recent Efforts to Improve "Recovery" . . . . . . . . . . . . 5

1.2.2 Definition of Recovery and the Stages of Recovery . . . . . 6

1.2.3 Length of Recovery after Colorectal Surgery . . . . . . . . 7

1.3 Prehabilitation .................. 8

1.3.1 Theoretical Framework . . . . . . . . . . . . 8

1.3.2 Previous Exercise-only Trial . . . . . . . . . . . . . 8

1.3.3 Trimodal Prehabilitation . . . . . . . . . . . . . . 9

2 Literature Review . . . . . . . . . . . . . . . . . . . . . . 11

$2.1 \quad$ Preoperative Exercise . . . . . . . . . . . . . . . . . . 11

2.1.1 General Benefits and Recommendations . . . . . . . . . . 11 
2.1.2 Impact of Physical Fitness on Colorectal Cancer Surgery . 11

2.1.3 Preoperative Training Programs . . . . . . . . . . . . . . . 12

2.2 Nutritional Therapy . . . . . . . . . . . . . . . . . . 15

2.2.1 Impact of Malnutrition on Colorectal Cancer Surgery . . . 15

2.2.2 Theoretical Benefits of Whey Protein Supplementation . . 16

2.3 Anxiety Reduction . . . . . . . . . . . . . . . . . 17

2.3.1 Psychological Status before Surgery . . . . . . . . . . . 17

2.3.2 Effects of Anxiety on Surgical Recovery . . . . . . . . . . . 18

2.4 Summary . . . . . . . . . . . . . . . . . . . 19

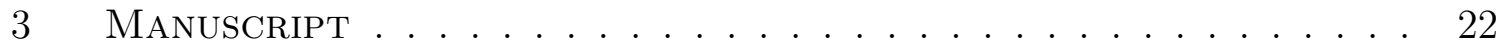

3.1 Manuscript Abstract ................. . . 23

3.2 Introduction . . . . . . . . . . . . . . . . . . 25

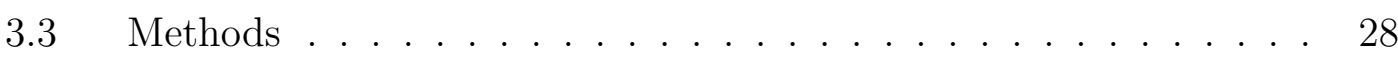

3.3.1 Subjects . . . . . . . . . . . . . . . . . 28

3.3.2 Interventions . . . . . . . . . . . . . . . . . . . . 30

3.3.3 Outcomes and measures . . . . . . . . . . . . . 31

3.3.4 Statistical methods ................ . . 33

3.4 Results . . . . . . . . . . . . . . . . 34

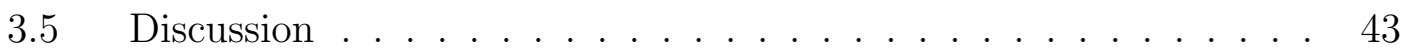

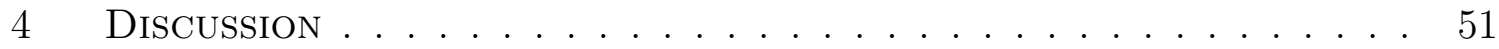

$4.1 \quad$ Improvement During Prehabilitation Phase . . . . . . . . . . . . . 51

$4.2 \quad$ Prehabilitation and Postoperative Recovery . . . . . . . . . . . . 53

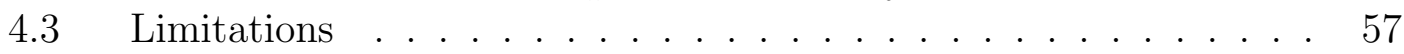

4.4 Future Considerations . . . . . . . . . . . . . . 60

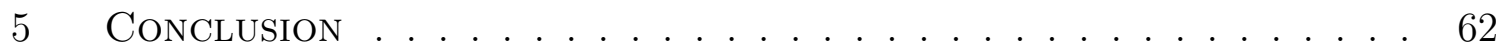

List of RefERENCES . . . . . . . . . . . . . . . . . . 63

Appendix A: Research Instruments - Short Form 36 Questionnaire . . . . . . 72

Appendix B: Research Instruments - CHAMPS Questionnaire . . . . . . . . . 77

Appendix C: Research Instruments - HADS Questionnaire . . . . . . . . . 81 
1-1 Proportion of new colorectal cancer diagnosis by age group . . . . . . 2

1-2 Colorectal cancer 5-year survival by AJCC stage . . . . . . . . . . . . 4

3-1 Patient characteristics at study enrolment . . . . . . . . . . . . 35

3-2 Surgical information and outcomes . . . . . . . . . . . . . . . 37

3-3 Functional outcomes . . . . . . . . . . . . . . . . . . . . 39

3-4 Health-related quality of life . . . . . . . . . . . . . . . 40

3-5 Multivariate analysis of significant factors influencing recovery of functional walking capacity . . . . . . . . . . . . . . 44 
1-1 Theoretical model of functional capacity $\ldots \ldots \ldots \ldots$

3-1 Flow diagram describing patient assessments and interventions . . . . 29

3-2 Trajectory of change in functional walking capacity . . . . . . . 38

3-3 Change in self-reported physical activity . . . . . . . . . . 40

3-4 Proportion of patients having recovered to baseline at 8 weeks . . . 43 


\section{LIST OF ABBREVIATIONS}

6MWT: Six-minute walk test

AJCC: American Joint Committee on Cancer

ASA: American Association of Anesthesiologists

BMI: Body mass index

CHAMPS: Community Health Activities Model Program for Seniors

CI: Confidence interval

HADS: Hospital Anxiety and Depression Scale

HRQL: Health-Related Quality of Life

MCS: Mental Component Summary

PCS: Physical Component Summary

SD: Standard deviation

SEER: Surveillance Epidemiology and End Results

SF-36: Medical Outcomes Study Short Form 36 Questionnaire 


\section{CONTRIBUTION OF AUTHORS}

Berson Augustin: data collection and organization

Chao Li: data collection, statistical analysis, manuscript drafting and revision

Do Jun Kim: physical training component, data collection

Dr. Ann Gamsa: anxiety reduction component

Dr. Barry Stein: colorectal surgery

Dr. Francesco Carli: trial design, data collection, supervision, revision of manuscript

Dr. Lawrence Lee: statistical consulting, revision of manuscript

Dr. Liane Feldman: trial design, supervision, revision of manuscript

Dr. Melina Vassiliou: supervision

Dr. Mingkwan Wongyingsinn: trial design, data collection

Dr. Patrick Charlebois: colorectal surgery

Dr. Sender Liberman: colorectal surgery

Pepa Kaneva: statistical consulting, supervision 


\section{ACKNOWLEDGEMENTS}

I would like to thank my supervisors Dr. Liane Feldman and Dr. Francesco Carli for their continued enthusiasm, support, and patience. It is only through their careful guidance that I have grown not only as a researcher but also as a human being. They have taught me the meaning of dedication and I will always continue to admire them.

I would like to extend my thanks to all the members of the SteinbergBernstein Centre for Minimally Invasive Surgery: Dr. Gerald Fried, Dr. Melina Vassiliou, Dr. Amy Neville, Dr. Lawrence Lee, Dr. Andrea Petrucci, Dr. Yo Kurashima, Annie Ncuti, Juan Mata and Benjamin Mappin-Kasirer for sharing the better part of a year and half with me and for helping me in countless ways. I would like to thank my collaborators from the Department of Anesthesia: Berson Augustin, Chelsia Gillis, and Rushami Aswathi. They are wonderful professionals

that treat patients with care, insight, and empathy and prehabilitation could never have happened without them. 


\begin{abstract}
BACKGROUnd: Patients undergoing colorectal cancer resections are at risk for delayed recovery. A previous prehabilitation program using exercise alone has shown limited impact in enhancing functional capacity and recovery. We compared the impact of a new trimodal prehabilitation program which includes exercise, nutritional and psychological therapy to patients undergoing standard care.

LiterAture REVIEW: Limited literature exists in enhancing functional capacity in abdominal surgery. Studies have focused on exercise alone and have reported negative results. Protein supplementation combined with exercise may stimulate muscle gain and anxiety reduction may improve compliance and recovery.

Methods: In this pre/post intervention study, functional walking capacity during prehabilitation and at 8 weeks after surgery was compared between 42 patients having completed the trimodal prehabilitation intervention and 45 previously assessed controls.

RESULTS: Functional walking capacity improved by an average $42 \pm 41$ meters during prehabilitation. At 8 weeks after surgery, patients undergoing prehabilitation were 64 meters above controls on multivariate analysis. $81 \%$ of prehabilitated patients were considered recovered versus $40 \%$ of controls. There was no difference in postoperative complication rates.

ConClusion: A trimodal prehabilitation program improved both functional capacity preoperatively and postoperative functional recovery.
\end{abstract}

ix 


\begin{abstract}
ABRÉGÉ
Contexte: Les patients subissant une résection pour cancer colorectal sont à risque d'un rétablissement retardé. Un programme de préhabilitation d'exercice physique seul a démontré un impact limité. Nous avons comparé l'impact d'un nouveau programme de préhabilitation trimodale qui inclut l'exercice, la nutrition, et la psychologie aux patients recevant des soins standard.

Revue De LA Littérature: Peu d'études existent sur l'amélioration de la capacité functionelle en chirurgie abdominale. Ces études ont mis l'accent sur l'exercice seul et ont eu des résultats négatifs. La supplémentation en protéines combiné avec l'exercice peut stimuler le gain de muscle, et la réduction de l'anxiété peut améliorer la participation et le rétablissement.

MÉThodes: Dans cette étude pré/post intervention, la capacité fonctionelle de marche durant la période de préhabilitation et à 8 semaines après la chirurgie ont été comparé entre 42 patients ayant terminé la préhabilitation trimodale et 45 contrôles évalués antérieurement.

RÉSultats: La capacité fonctionnelle de marche s'est ameliorée de $42 \pm 41$ mètres lors de la préhabilitation. À 8 semaines, les patients ayant terminé la préhabilitation étaient 64 mètres au-dessus des contrôles sur analyse multivariée. $81 \%$ des patients en préhabilitation s'étaient rétablis versus $40 \%$ des contrôles. Il n'y avait aucune différence dans les taux de complications postopératoires. Conclusion: Un programme de préhabilitation trimodale a amélioré à la fois la capacité fonctionelle en préoperatoire et le rétablissement postopératoire.
\end{abstract}




\section{PREFACE}

The following is a manuscript-based thesis investigating the effects of a novel, trimodal prehabilitation program on functional recovery after colorectal surgery. The abstract was accepted for oral presentation at the Society of American Gastrointestinal and Endoscopic Surgeons March 2012 annual meeting and the associated manuscript as presented here was accepted for publication in Surgical Endoscopy as of August 2012. The manuscript is provided with kind permission from Springer Science+Business Media B.V. 


\section{CHAPTER 1}

\section{BACKGROUND}

\subsection{Colorectal Cancer}

\subsubsection{Epidemiology}

Over 500 Canadians are diagnosed with cancer every day. Colorectal cancer is the third most frequently diagnosed cancer type, accounting for $13 \%$ of all new diagnoses. In Canada, there will be an estimated 23,300 new cases of colorectal cancer in 2012 alone [1]. In Canadian registries, the trend of incidence rates has remained stable among men and is decreasing among women between 1983 and 2000 though it remains higher than that in the United States and many European countries. Still, approximately one person out of twenty will develop colorectal cancer in their lifetime.

Colorectal cancer also accounts for a significant burden of overall cancer mortality, with 9,200 deaths expected in Canada, a 12\% share of all cancerrelated deaths. Canadian mortality rates, however, have decreased by $2.6 \%$ for men and have remained stable for women over the last 20 years mostly due to improved treatment options and early screening programs which allow both decreases in incidence from removal of precancerous polyps, and in mortality from earlier detection of malignant lesions [1]. Nonetheless, the worldwide burden of disease continues to progress, especially due to an increase in westernized lifestyle and diet [2]. Mortality rates also remain problematic, particularly in countries 
lacking the resources and health infrastructure to permit an adequate screening program [3].

\subsubsection{Pathophysiology and Clinical Presentation}

Although genetic diseases such as familial adenomatous polyposis and hereditary nonpolyposis colon cancer can predispose to syndromic colon cancer, the sporadic form is by far the most common. A well described adenoma-to-carcinoma sequence explains the development cycle from normal mucosa to malignant can-

cer [4]. Most lesions begin as pre-malignant adenomatous polyps after mutation of the $A P C$ gene. Malignant characteristics then typically develop over a matter of years as successive genetic mutations accumulate, most prominently mutations in the $K$-ras and $p 53$ oncogenes, which lead to progressive loss of cell cycle control and malignant transformation.

Table 1-1: Proportion of new colorectal cancer diagnosis by age group

\begin{tabular}{lr}
\hline Age group & Proportion \\
\hline Under 20 & $0.1 \%$ \\
$20-34$ & $1.1 \%$ \\
$35-44$ & $3.0 \%$ \\
$45-54$ & $13.4 \%$ \\
$55-64$ & $20.4 \%$ \\
$65-74$ & $24.0 \%$ \\
$75-84$ & $25.0 \%$ \\
Above 85 & $12.0 \%$ \\
\hline
\end{tabular}

Adapted from SEER data 2005-2009 [5]. 
Although colorectal cancer can occur in younger individuals, the main non-modifiable risk factor is age. Colorectal cancer thus tends to occur in older patients, with 9 out of 10 diagnoses made on patients above 50 and the majority on patients aged above 65 years (Table $1-1$ ). The median age at diagnosis is 69 years [5]. Other risk factors include personal history of previous adenomas, family history of colorectal cancer, and the presence of inherited syndromes. Colorectal cancer is also associated with westernized lifestyle and diet. These are modifiable risk factors and the most important evidence points towards obesity, central adipose distribution, and lack of physical activity. Other, more controversial, risk factors include processed meat, alcohol consumption, and cigarette smoking [6].

The development of colorectal cancer is usually silent and is not accompanied by overt symptoms until late in the disease. Symptoms associated with colorectal cancer early in the disease are usually vague and include abdominal pain, change in bowel habits, weakness and fatigue, and occult blood loss. In later stages, depending on the location of the tumour, these which may progress to hematochezia or melena, involuntary weight loss, and obstruction [7].

Staging for colorectal cancer follows the American Joint Committee on Cancer recommendations, which is based on tumour, node, and metastasis (TNM) information [9]. In general, stage I tumours are localized and do not invade the muscularis propria, stage II tumours invade through the muscularis propria but do not have positive nodal status, stage III tumours have nodal involvement, and stage IV tumours have metastasized. The overall 5-year survival was $65 \%$ in the United States from 1991 to 2003 [8]. Though cancer-related mortality 
Table 1-2: Colorectal cancer 5-year survival by AJCC stage

\begin{tabular}{lrr}
\hline AJCC stage & Distribution & 5-year survival \\
\hline I & $15.1 \%$ & $93.2 \%$ \\
IIa & $29.7 \%$ & $84.7 \%$ \\
IIb & $6.1 \%$ & $72.2 \%$ \\
IIIa & $2.0 \%$ & $83.4 \%$ \\
IIIb & $16.6 \%$ & $64.4 \%$ \\
IIIc & $8.9 \%$ & $44.3 \%$ \\
IV & $21.6 \%$ & $8.1 \%$ \\
\hline Total & & $65.2 \%$ \\
\hline
\end{tabular}

Adapted from SEER data 19912000 [8].

is infrequent with localized tumours (stage I \& II), a more extensive burden of disease, especially if there are metastases, is associated a significant decrease in 5-year survival (Table 1-2).

\subsubsection{Treatment Strategies}

The significantly better prognosis of earlier stage lesions, the existence of a detectable and removable precursor lesion, and the presence of adequate detection strategies are the basis behind early screening programs. The goal is for asymptomatic individuals to be tested to either detect colorectal cancer at an earlier stage or to find and remove pre-malignant lesions endoscopically. Screening is recommended for all average-risk individuals aged above 50, and earlier for those at higher risk. Current best evidence suggests using fecal occult blood testing yearly as a first line strategy followed by flexible sigmoidoscopy every 5 years [10]. All Canadian provinces have either developed or are in development 
of a systematic program using fecal occult blood testing as primary screening followed by colonoscopy for any positive results [11].

Due to the local nature of the disease, the traditional primary approach to colorectal cancer and the only curative approach is surgery. The National Comprehensive Cancer Network guidelines for colon cancer suggest colectomy up-front unless the tumour is unresectable due to locally advanced disease. Even in cases of lung or liver metastases, if they are resectable, synchronous or staged colectomy and metastatectomy is recommended [12]. Similarly, surgery is recommended as the first-step in treatment for T1 or T2 tumours, and as second step after neoadjuvant therapy for all more extensive resectable tumours [13]. Therefore, surgery is an essential treatment in the vast majority of colorectal cancer diagnoses.

\subsection{Recovery after Surgery}

\subsubsection{Recent Efforts to Improve "Recovery"}

Colorectal surgery has been associated with a difficult postoperative period, with all-cause morbidity around $23 \%$ and an average length of hospital stay of 10 days [14]. Though the past decade, the adoption of strategies to improve recovery after colorectal surgery has begun. Techniques such as minimally invasive surgery and enhanced recovery pathways have claimed reduce surgical stress and to enable a quicker recovery from a traditionally difficult operation. Large prospective trials have shown that laparoscopic operations have, for instance, been associated with improving return to bowel function, diminishing postoperative pain, and a reduction in length of hospital stay $[15,16]$, without detrimental 
long term oncologic results [17]. Similarly, enhanced recovery pathways have primarily impacted hospital stay, with a trend towards decreasing postoperative complications [18]. These advantages seem concentrate on the immediate shortterm postoperative period, which is the first few days after the surgery up until patient discharge.

\subsubsection{Definition of Recovery and the Stages of Recovery}

Despite the attention placed upon it, the concept of recovery from surgery may be inadequately covered by the limited time that the immediate postoperative period represents. There is no clear definition for recovery in the literature. It is a complex, continuous transition through the entire surgical process, and may only end when the patient has regained their preoperative health status [19]. Three overlapping stages of recovery have been identified, where the early recovery stage covers the awakening and recovery of vital reflexes, intermediate recovery details clinical recovery until home readiness, and late recovery is achieved when full physical and psychological recovery is achieved [20].

The Wilson-Cleary model may be used to better understand the relationship between lower and higher level measures of health and can be applied to recovery [21]. It describes five progressive levels of health measures: biological and physiological variables, symptom status, functional status, general health perceptions, and overall quality of life. Measurement of impact on recovery has traditionally focused only on the early and intermediate recovery stages. These measures often include length of hospital stay and morbidity, which correspond to symptom status, but few measures are focused on the late recovery period and on 
patience-centered outcomes such as functional status. The late recovery stage may have more impact for patients' well-being compared with earlier stages.

\subsubsection{Length of Recovery after Colorectal Surgery}

We have previously investigated both late stage functional recovery using the Six-minute walk test (6MWT), a test of functional walking capacity, and quality of life using the Medical Outcomes Study Short Form 36 (SF-36) questionnaire (see section 3.3.3), after colorectal cancer surgery [22]. This trial, designed to compare epidural anesthesia to patient controlled anesthesia, found benefit for the former both at 3 and 6 weeks after surgery. More importantly, it showed that regardless of the group, patients only returned near their preoperative 6MWT results 6 weeks after surgery, and continued to exhibit lower results of physical domains of their quality of life. A recent study amalgamated data from five randomized controlled trials analyzing effects colorectal surgery on physical function and fatigue after discharge [23]. 30 days after surgery, patients continued to experience higher fatigue scores and lower muscle strength as measured by hand grip and knee extension. Fatigue and physical functioning related quality of life scores may remain below baseline even 3 months after surgery [16]. The late recovery stage may thus stretch for a much longer period than is typically thought.

Although minimally invasive surgery and enhanced recovery programs have improved intermediate recovery, improvement in recovery back to baseline quality of life status has not been shown and little literature exist on interventions designed to improve functional recovery $[16,24]$. These interventions were not 
designed to improve late functional recovery and were focused on improving the perioperative care of patients.

\subsection{Prehabilitation}

\subsubsection{Theoretical Framework}

"Prehabilitation" is defined as an intervention designed to improve functional capacity in anticipation of an upcoming surgical stressor. We postulate the effects of preoperative functional capacity on postoperative recovery in the model of recovery of functional status show in Figure 1-1. By using the preoperative period to administer a prehabilitation intervention, patients can improve above their baseline physical status, mitigate the detrimental effects of surgery on their functional capacity, and thus return to normal function at a much earlier time. Patients may also be better prepared physically to face the stress of surgery, and may derive benefits in the early and immediate phases. Thus, using the preoperative period to improve functional capacity has the potential to both improve patient fitness for surgery and to quicken their time to full recovery.

\subsubsection{Previous Exercise-only Trial}

Our first investigation into prehabilitation was done in the 2005-2006 period. A two-arm randomized controlled trial compared patients undergoing a structured exercise program focused on stationary biking to a "sham" intervention group who received general instructions to walk and do breathing exercises. To our surprise, the structured biking group did not show significant improvement in functional capacity as measured by the 6MWT both during the prehabilitation period and during the recovery period compared to the sham intervention. Also, 


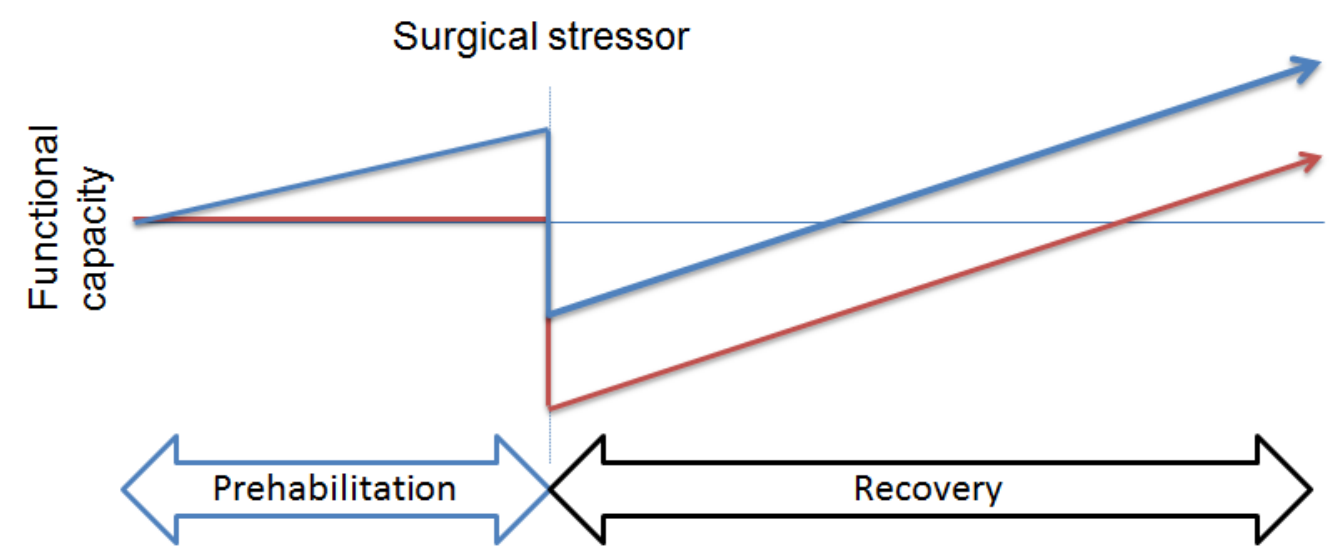

Figure 1-1: Theoretical effect of prehabilitation on recovery of functional capacity after surgery. The blue arrow represents a patient undergoing prehabilitation whereas the red arrow represents traditional care [25]

more patients in the sham intervention group showed improvement in walking capacity during prehabilitation ( $47 \%$ vs $22 \%$ ). There was poor compliance to stationary biking guidelines and $29 \%$ of patients deteriorated while waiting for surgery despite intervention [26]. We also found that patients who were responsive to the prehabilitation intervention were more likely to have recovered to baseline function 9 weeks after surgery. Key variables that predicted poorer recovery included female sex, low baseline 6MWT, higher co-morbidity (American Society of Anesthesiologists (ASA) scores), and high anxiety [27].

\subsubsection{Trimodal Prehabilitation}

We used this information to construct a new prehabilitation intervention. Variables such as anxiety were found to impact functional recovery which demonstrates the complex interplay between mental and physical factors in recovery. 
Moreover, adequate nutritional substrate may not have been provided to patients for exercise to have a maximal effect on gain in muscle mass and physical function. We therefore propose a trimodal prehabilitation program integrating nutritional supplementation with whey protein and anxiety reduction strategies to a moderate exercise program. The following literature review and manuscript describe the existing knowledge supporting the current use of these three modes of intervention and the results of a prospective cohort trial. 


\section{CHAPTER 2 \\ LiteratuRE REVIEW}

\subsection{Preoperative Exercise}

\subsubsection{General Benefits and Recommendations}

Despite the results of our initial exercise-only trial on prehabilitation, we believe that exercise remains the cornerstone of any intervention designed to enhanced functional capacity. The benefits of a physically active lifestyle are innumerable. Physical activity and fitness, especially in the elderly population which is most at risk for colorectal cancer, has been shown to lessen all-cause mortality, morbidity, and disability, and to be beneficial in cardiovascular and respiratory disease, and even in cancer [28]. The American College of Sports Medicine and the American Heart Association have issued a joint recommendation that regular physical activity is essential for healthy aging and should include moderate-intensity aerobic activity for 30 minutes five times per week combined with muscle-strengthening, balance, and flexibility exercise [29].

\subsubsection{Impact of Physical Fitness on Colorectal Cancer Surgery}

Higher levels of physical activity are associated with significantly reduced risk for incidence in colorectal cancer and low physical activity is considered a risk-factor for its development [30,31].

Moreover, better physical fitness has been associated with improved shortterm surgical outcomes. Reilly et al. have documented a two-fold increase in 
incidence of serious postoperative complications after major non-cardiac surgery in patients who self-reported poor exercise tolerance [32]. Dronkers et al. have identified an association between poor physical activity levels (odds ratio (OR) 5.5) and poor inspiratory muscle endurance (OR 5.2) on short-term mortality after major oncologic abdominal surgery [33]. Wilson et al. have found that an aerobic threshold of lower than $10.9 \mathrm{ml} / \mathrm{kg} / \mathrm{min}$ was associated with a relative risk of 6.8 for all-cause in-hospital and 90 day mortality after colorectal resection [34]. Nutt and Russell have found that patients with poor preoperative 6MWT results were more likely to develop postoperative complications and proposed a cut-off distance of 250 meters, which had a specificity of 0.88 and a sensitivity of 0.58 in their cohort [35].

In our previous prehabilitation trial, regardless of the intervention undertaken (biking or walking and breathing), patients who deteriorated in functional capacity while waiting for surgery had higher risk for complications requiring reoperation or intensive care use [27]. An audit of our own data has also shown an association between low preoperative 6MWT result and cardiopulmonary complications after colorectal surgery. A 392 meter cut-off yielded an odds ratio of 5.3, with a specificity of 0.74 and a sensitivity of 0.72 for predicting the occurrence of cardiopulmonary complications [36]. Therefore, since physical fitness is a modifiable risk-factor for postoperative complications, it would seem advantageous to use the preoperative period to improve fitness in a structured prehabilitation program.

\subsubsection{Preoperative Training Programs}

\section{Oncologic Abdominal Surgery}


Other than trials conducted by our group, a single trial has been identified using exercise to improve functional capacity prior to abdominal oncologic surgery. Dronkers et al. performed a pilot randomized controlled study to assess the feasibility of a short-term intensive therapeutic exercise program to improve muscle strength, aerobic capacity, and functional activities [37].

The intervention group used in this trial was a training program given both at home and at an outpatient physical therapy hospital department in the Netherlands compared with a control group asked only to follow the home based program. Sixty minute outpatient training sessions were given twice a week and included resistance training of the leg muscles, inspiratory muscle training, aerobic training, and a flexible module on functional activities tailored to the patient's capabilities. The home portion of the program prescribed walking or cycling for 30 minutes per day. They also received instruction in deep breathing exercises.

After an average of 5 training sessions, the authors found only an improvement in inspiratory muscle endurance in the group undergoing both outpatient and home program . There were no significant gains in functional capacity during prehabilitation in both groups, including Timed-Up-and-Go, chair rise time, cycle ergometer test, physical activity questionnaires, pedometer steps recorded, and quality of life measures. Postoperative complications and length of hospital stay were also the same. The authors, however, do distinguish that patients with a pedometer recording below 4000 steps per day were more likely to suffer from postoperative respiratory complications, regardless of the training program that they received. 
The authors state that they were successful in establishing the feasibility of prehabilitation in the abdominal population and found improved respiratory muscle function. They may have been unable to find a difference between the two groups as both arms were relatively similar in treatment, with the intervention group only benefiting from a few extra supervised outpatient visits. Moreover, they did not find improvement during the prehabilitation phase, though scores remained relatively stable. In contrast, we have found in our previous trial that a significant proportion of patients tend to deteriorate while waiting for surgery. Mitigation of this deterioration may be a significant result in itself. These results could have been found if they had used a control group which had not received any recommendations. Finally, prehabilitation studies have thus far only focused on exercise and have not combined exercise training with other modes of training. Other Types of Surgeries

Far more prehabilitation trials have been undertaken for both cardiovascular and orthopedic surgeries than for abdominal operations. In cardiovascular surgery, the main focus for preoperative intervention is in the domain of inspiratory muscle training prior to coronary artery bypass surgery. The usual regimen requires patients to perform inspiratory muscle exercise at an intensity of $20 \%$ of maximal inspiratory pressure for a minimum of 15 minutes daily. It is recommended to start the program from 2 to 4 weeks prior to surgery. A recent review and a metaanalysis have found evidence to support the use of inspiratory muscle training as they decrease atelectasis and pulmonary complications with a risk ratio of 0.4 , and improve maximal inspiratory pressure by up to $36 \%[38,39]$. 
In orthopedic surgery, the main focus is strengthening and flexibility of the lower limbs in preparation for either knee or hip joint replacement. In general, outcome measures included joint specific strength measures, surgery specific questionnaires, length of hospital stay, and quality of life. The majority of trials do not show benefit in their outcomes and a meta-analysis of the results did not show significant benefit in terms of postoperative complications and hospital length of stay $[38,39]$.

\subsection{Nutritional Therapy}

\subsubsection{Impact of Malnutrition on Colorectal Cancer Surgery}

Colon cancer patients may have a variety of non-specific gastrointestinal and abdominal symptoms such as abdominal pain and bloating which inhibit the ability to maintain adequate caloric intake. Moreover, the malignancy itself may exert a chronic systemic inflammation response which manifests itself as weight loss and cachexia [40]. Over half of patients presenting for colorectal resection will have had significant preoperative weight loss and up to $20 \%$ of patients will have lost more than $10 \%$ of their body weight $[41,42]$.

Patients having lost weight tend to have poorer muscle strength as measured by hand-grip test, especially as the lost weight will mostly consist of muscle mass [42]. A large population-based studies have identified preoperative malnutrition as an independent predictor, with an odds ratio of 1.33, for mortality after colorectal cancer surgery [43]. Significant preoperative weight loss has also been linked with specific postoperative complications such as anastomotic leak [44], and 
have been associated with prolonged length of hospital stay and increased costs for hospitalization $[41,45]$.

\subsubsection{Theoretical Benefits of Whey Protein Supplementation}

Whey proteins are the fraction of milk proteins that do not coagulate to form curds and are by-products of the cheese-making industry. They are rich in antibodies and in branched-chain amino acids and are considered highly nutritious. In patients with malnutrition, whey protein supplementation could be seen as an additional source of valuable nutrition. However, the majority of colorectal cancer patients are not considered malnourished.

In our context, then, whey protein is used to ensure appropriate nutrition is provided in adequate amounts to optimally stimulate improvement in muscle mass and functional capacity when performing physical exercise. The protein needs of patients engaged in an exercise program can be double that of sedentary individuals [46]. Exercise and protein supplementation have a synergistic effect. Exercise supplemented by protein has been shown to increases fat-free mass gain and improves maximum leg press strength [47]. Muscle protein synthesis has also been found to be higher when taking small amounts of whey protein compared to

carbohydrates in young volunteers after resistance exercise [48]. Finally, volunteers taking whey protein during an extended 6 week training program were found to have superior lean tissue mass as measured by x-ray absorptiometry and greater bench press strength and knee extension torque [49]. Thus, patients undertaking a new exercise program may require increased protein intake, and whey protein 
supplementation combined with resistance exercise appears to provide benefits in muscle mass and strength gained.

Whey proteins have been postulated to possess anti-inflammatory and immunoenhancing effects, which would be mediated through their effect on the glutathione pathway. Whey proteins contain substantial concentrations of cysteine. Cysteine is the rate limiting substrate on the pathway leading to glutathione synthesis. Glutathione in its reduced form has the ability to neutralize other unstable molecules such as reactive oxygen species and is thus a key mechanism in offsetting oxidative damage. Thus, it was found that mice fed with whey protein achieved higher levels of humoral immunity than mice fed with any other milk-derived protein and that these mice have an associated increase in splenic glutathione production [50]. Since then, it has been proposed that whey protein may have protective effects against the development of several cancers [51]. Finally, research in colorectal cancer have shown that dietary whey protein has an inhibitory effect on the development of tumours after exposition to azoxymethane, a known cancer-inducing agent, in rats $[52,53]$. Therefore, although clinical results are not available, there is laboratory evidence that dietary whey protein may actively prevent cancer development.

\subsection{Anxiety Reduction}

\subsubsection{Psychological Status before Surgery}

The preoperative period is a difficult time period for patients. They are often juggling the relatively new diagnosis of a potentially deadly malignancy with multiple appointments in preparation for surgery. They experience worry 
about the outcome of the operation and express fear of the uncertain and of death. Moreover, most patients undergoing operations for malignancy experience increased anxiety as the days progress during the waiting period and may express ambivalence at handing over their body to healthcare staff [54].

Qualitative data have identified six major thought themes in colorectal cancer patients: seeking an understanding of the personal significance of the diagnosis; looking at the consequences; reviewing life; change in outlook towards self, life, and others; living with cancer; and hope [55]. For many patients, the diagnosis of cancer thus comes as a profound change in their identity. This time period of existential searching may be well harnessed to introduce lifestyle initiatives and behaviour modification that may have a lasting impact after the cancer has been dealt with.

\subsubsection{Effects of Anxiety on Surgical Recovery}

The effects of anxiety can be wide ranging and may have a subtle impact on multiple domains of recovery. Psychological stress has been associated with the slower healing of superficial wounds, in part due to higher levels of glucocorticoids. Patients undergoing hernia repair with greater preoperative perceived stress were found to have lower cytokine levels in the wound fluid, more pain, and a lengthier recovery $[56,57]$. A theoretical framework has been proposed that links psychological status with general health status, pain, neuroendocrine function, immune function, and wound healing [58].

Mavros et al. have performed a systematic review of the impact of psychosocial status on postoperative outcomes [59]. They have found that perceived 
stress and worry about the operation have both been associated with attenuated recovery, postoperative complications, and impaired wound healing in elective surgery. For instance, patients trained in relaxation techniques were found to have less pain 1, 3, and 30 days after cholecystectomy and were quicker to return to normal daily activities [60]. The studies reported were widely heterogeneous but the authors conclude that the psychosocial status may influence surgical recovery and psychological preparation for surgery may improve outcomes.

In our previous randomized controlled trial, moderate $(5.6 \%)$ or high $(10.2 \%)$ levels of anxiety were associated with improvement in functional walking capacity during the prehabilitation phase. However, during the follow-up period, anxiety was a significant predictor of worsened recovery to baseline functional capacity, with average values $-9.7 \%$ below baseline for patients with Hospital Anxiety and Depression scale score of 5 to 7 , and $-14.1 \%$ for those with scores above 8 (above 7 is considered clinical anxiety) [27].

\subsection{Summary}

Physical activity is an integral part of healthy life for everyone, but especially for older adults. Higher levels of physical activity is protective against mortality, morbidity, and disability. Patient with low physical fitness are less able to confront the stress of colorectal surgery and are at higher risk for complications. Prehabilitation may have a role to play in enhancing fitness before surgery. There is one study of prehabilitation in abdominal surgery other than from our group and this study has shown only improved inspiratory muscle function, but no improvement in functional capacity, questionnaire scores, or quality of life. Our 
own previous randomized controlled trial found no benefit to an intense stationary cycling program when compared with general recommendations for walking and breathing. Studies of prehabilitation in cardiovascular and orthopedic surgery have only shown benefit for inspiratory muscle training and reduction of pulmonary complications. No clear advantage has been found for improving overall functional capacity. The applicability of this data to colorectal cancer patients is questionable due to the nature and location of the surgery. Finally, none of these studies use modes other than exercise to achieve enhancement of functional recovery.

Nutritional supplementation with whey protein has multiple advantages. For patients a small proportion of patients who may already be malnourished or who are losing weight, it may act as a nutritious supplement to help counteract weight loss. For the majority of patients, starting an exercise program increases protein intake requirements. Whey protein, when used in combination with an exercise program, can ensure the appropriate substrate is available for optimal development of muscle mass and can promote greater gains in muscle strength. Finally, though theoretical, there may be potential oncologic benefits through immunoenhancement.

The preoperative period can also be a difficult time period for patients awaiting colorectal cancer surgery. It is often filled with anxiety and self-searching. Anxiety has multiple subtle impacts on not only mental well-being but also on immunological parameters, perception of pain, and wound healing. In our previous randomized trial, although patients who were anxious were more likely to increase their functional capacity during the prehabilitation phase, in the end, they were 
less likely to have recovered to baseline on follow-up evaluation. Anxiety was therefore seen as a barrier to postoperative recovery. There is promise that the addition of a psychological intervention based on anxiety reduction and relaxation may help quicken recovery and return to baseline function. 
CHAPTER 3

MANUSCRIPT

Surg Endosc

DOI $10.1007 / \mathrm{s} 00464-012-2560-5$

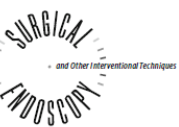

\section{Impact of a trimodal prehabilitation program on functional recovery after colorectal cancer surgery: a pilot study}

Chao Li · Francesco Carli $\cdot$ Lawrence Lee $\cdot$ Patrick Charlebois $\cdot$ Barry Stein •

Alexander S. Liberman · Pepa Kaneva - Berson Augustin · Mingkwan Wongyingsinn •

Ann Gamsa · Do Jun Kim · Melina C. Vassiliou • Liane S. Feldman

Received: 18 May 2012/Accepted: 21 August 2012

(C) Springer Science+Business Media, LLC 2012 


\subsection{Manuscript Abstract}

BACKGRound: Patients undergoing colorectal cancer resections are at risk for delayed recovery. Prehabilitation aims to enhance functional capacity preoperatively in order to better tolerate surgery and to facilitate recovery. We previously demonstrated limited impact of a prehabilitation program using exercise alone. We propose an expanded trimodal prehabilitation program that adds nutritional counseling, protein supplementation and anxiety reduction to a moderate exercise program. The purpose of this study was to estimate the impact of this trimodal program on recovery of functional capacity compared to standard surgical care.

Methods: Consecutive patients were enrolled in this pre/post intervention study over a 23-month period. Postoperative recovery in 42 consecutive patients enrolled in the prehabilitation program was compared with a cohort of 45 patients assessed before the intervention began. The primary outcome was functional walking capacity (Six-minute walk test (6MWT)). Secondary outcomes included self-reported physical activity (CHAMPS questionnaire) and health-related quality of life (SF-36). Data are expressed as mean \pm sd or median[IQR], and analyzed using $\chi^{2}$ and Student's $t$ tests. $P<0.05$ was considered significant.

RESUlts: The prehabilitation and control groups were comparable in age, gender, BMI and ASA class. There was no difference in walking capacity at first assessment (6MWT distance $422 \pm 87 \mathrm{~m}$ vs $402 \pm 57 \mathrm{~m}, p=0.21$ ). During the prehabilitation period lasting a median 33 [21-46] days, functional walking capacity improved by $42 \pm 41 \mathrm{~m}(p<0.01)$. Postoperative complication rates and 
duration of hospital stay were similar. Patients in the prehabilitation program had better postoperative walking capacity at both 4 weeks (mean difference $51.5 \pm 93 \mathrm{~m}$, $p=0.01)$ and 8 weeks $(84.5 \pm 83 \mathrm{~m}, p<0.01)$. At 8 weeks, $81 \%$ of prehabilitated patients were recovered compared to $40 \%$ in the control group $(p<0.01)$. The prehabilitation group also reported higher levels of physical activity before and after surgery.

CONCLUSION: In this pilot study, a one-month trimodal prehabilitation program improved postoperative functional recovery. 


\subsection{Introduction}

There were an estimated 100,000 new cases of colon cancer in the United

States in 2010 [61]. Despite recent advances in surgical, anesthetic, and perioperative care for colon surgery, morbidity is significant and patients are at risk for prolonged recovery. A large study identified colorectal resection as the general surgery operation with the greatest burden of adverse events and excess hospital stay [62]. With efforts focused on improving the quality of surgical care, there is increasing awareness that major postoperative complications may be driven more by patient rather than surgical factors alone [63].

The implementation of an Enhanced Recovery After Surgery program ("fast track surgery") reduces duration of hospital stay by 2 days after colorectal surgery [18]. However, patient-centered outcomes of functional capacity suggest that patients are not fully recovered even at 6 to 9 weeks after major abdominal surgery $[22,64]$. Poor preoperative physical fitness predicts mortality and major complications $[32,34]$ and delayed functional recovery after abdominal surgery [65].

Attempts to improve recovery have tended to focus on the intraoperative (e.g. laparoscopic surgery, thoracic epidural) and postoperative (e.g. enhanced recovery pathways) periods. However, intervening in the preoperative period to modify factors like poor physical fitness contributing to morbidity and delayed recovery is an attractive strategy. In cancer patients awaiting surgery, a 5 week preoperative exercise program was sufficient to measurably improve cardiorespiratory fitness and muscle strength [66]. Interventions designed to improve functional 
capacity in anticipation of an upcoming stressor such as surgery have been termed "prehabilitation" [25].

We previously reported a randomized study of an exercise-only prehabilitation intervention in colorectal surgery [26]. Patients were randomized to either an intense exercise regimen based on daily biking (intervention group) or a "sham" intervention consisting of a recommendation to walk daily and do breathing exercises (control group). The primary outcome was walking capacity as measured by the six-minute walk test $(6 \mathrm{MWT})$. Adherence to the recommendations was low, with only $33 \%$ improving during prehabilitation and $29 \%$ deteriorating despite the intervention. There was an unexpected benefit from the recommendation to increase walking and breathing, with more people in the control group showing an improvement in walking capacity both prior to surgery and after surgery. A reanalysis demonstrated that regardless of the type of exercise received, patients who improved during the prehabilitation period were more likely to have recovered nine weeks postoperatively [27].

Many factors may have influenced the results of our previous study. First, adherence to the intense stationary-bicycle based exercise program was low and results were poor. Colorectal cancer patients can have alterations in digestion from symptoms of the disease and changes to metabolism causing increased protein breakdown. Up to half of patients awaiting colon cancer surgery exhibit weight loss and up to one in five is malnourished [42]. Adequate protein substrate is necessary to allow for successful muscle gain during a physical exercise regimen, but nutritional status was not assessed or controlled for in this previous study. 
Moreover, while anxious patients showed a greater improvement in functional capacity during the prehabilitation period, they were ultimately less likely to recover to baseline after surgery [27]. Finally, perioperative surgical care was not standardized by an enhanced recovery pathway. These results suggested that an intervention based on exercise alone may not have been sufficient to enhance functional capacity if factors such as nutrition, anxiety, and perioperative care were not taken into consideration during the program.

In view of this, we formulated a new prehabilitation intervention adding nutritional and anxiety reduction interventions to a moderate exercise program. The goal of the nutritional intervention was to guarantee sufficient substrate to allow optimal effects of exercise. Whey proteins are a by-product of cheese making and serve as a highly nutritious supplement that can act synergistically with exercise to increase protein synthesis and muscle endurance $[67,68]$. In a 6 week exercise program, participants were found to have significant increases in strength gained while taking 1.2 grams per kilogram body weight in daily whey protein [49]. Whey proteins are also rich in essential and branched-chain amino acids and have shown both anti-inflammatory and immune-modulating properties [69, 70]. The goal of the anxiety reduction component was to allow patients to express their concerns to a psychologist and to become familiar with calming exercises used to reduce their perceived anxiety levels.

The purpose of this study was to estimate the impact of this new trimodal prehabilitation program on functional recovery after colorectal cancer surgery in the setting of an enhanced recovery pathway. 


\subsection{Methods}

\subsubsection{Subjects}

Consecutive patients awaiting elective surgery for primary colorectal cancer were assessed for enrollment in this prospective pre-post intervention study from July 2009 to September 2011 at a university teaching hospital. The trimodal prehabilitation intervention was initiated in September 2010. Postoperative recovery in patients enrolled in the trimodal prehabilitation program (intervention group) was compared with a cohort of 45 patients studied prior to the initiation of the intervention (control group). Inclusion criteria included adults with a colonic or rectal malignancy planned for resection. Exclusion criteria were the presence of metastatic disease or of any medical condition precluding the safe use of physical activity, and any patient unable to understand English or French sufficiently to accurately complete the questionnaires. Patients in both groups were cared for by one of three fellowship-trained colorectal surgeons and perioperative care was guided by a standardized enhanced recovery pathway established in our institution since 2008 [71]. Baseline patient characteristics, operative data, and postoperative complications were collected prospectively. The study was approved by the Research Ethics Board of the McGill University Health Centre.

Between July 2009 and September 2010, patients were approached at the preoperative centre and after consent was obtained, enrolled in the control group. They were assessed at three time points: At the time of recruitment (approximately one week prior to surgery), and at four and eight weeks after surgery. Starting in September 2010, patients were referred from the colorectal 
clinic after a decision was made to proceed with surgery (Figure 3-1). At the initial visit, the prehabilitation program was explained and informed consent obtained. Following a medical examination, patients met with the kinesiologist, nutritionist, and psychologist and baseline measures were obtained (see below for measures and interventions). Subjects then initiated the prehabilitation intervention at home. Length of prehabilitation was determined by the wait time until surgery alone. As in the control group, the intervention group was reassessed one week before surgery at the preoperative centre, and at four and eight weeks after surgery.

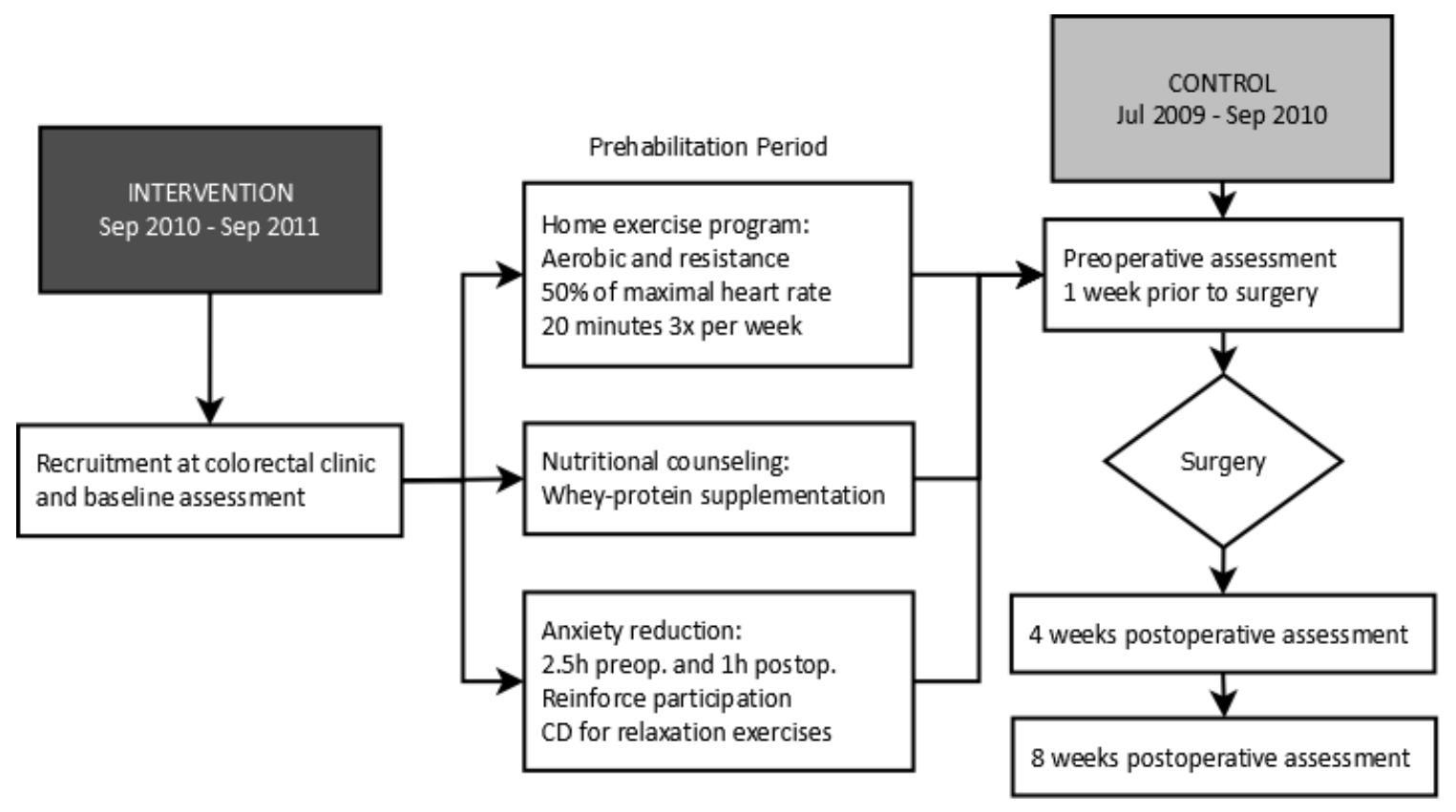

Figure 3-1: Flow diagram describing timing of patient assessments and interventions. All assessments included walking capacity (6MWT), self-reported physical activity (CHAMPS) and health-related quality of life (SF-36) 


\subsubsection{Interventions}

\section{Exercise}

Exercise remained the mainstay of the prehabilitation program. We combined moderate aerobic exercise with resistance training. A kinesiologist met with patients for one hour and planned an individualized exercise program and schedule. Patients were asked to walk or to use an aerobic exercise machine for 30 minutes three times a week. Target exercise intensity was set at half of calculated maximal heart rate $(220$ - age $)$ and was measured by the patient with a provided heart rate monitor. Resistance exercises consisted of calisthenics and elastic band movements performed three times a week to volitional fatigue.

\section{Nutrition}

Patients enrolled in the prehabilitation program were evaluated by a nutritionist in a one-hour visit. A subjective global assessment was carried out and one to two modifiable dietary behaviours such as excess alcohol or fat intake were identified and discussed with the patient [72]. Patients were provided with whey protein isolate (Vitalus Nutrition Inc, Abbotsford, Canada) which was used as nutritious food supplements in order to guarantee a daily intake of 1.2 grams per kilogram body weight of protein. Recipes to make intake palatable were given. Patients were asked to consume protein preferably within one hour of their exercise regimen.

\section{Anxiety Reduction}

Preoperatively, patients were scheduled for a ninety-minute visit with a trained psychologist focusing on providing anxiety reduction techniques such as 
relaxation exercises and breathing exercises. These exercises were mirrored on a compact disc for home practice. A primary goal of the psychological component was to enhance and reinforce patients' motivation to comply with the exercise and nutritional aspects of the intervention.

\subsubsection{Outcomes and measures}

The primary outcome was functional walking capacity as measured by the six-minute walk test (6MWT) 8 weeks after surgery. The $6 \mathrm{MWT}$ evaluates the capacity to maintain a moderate level of walking and reflects capacity to perform activities of daily living. In the 6MWT, the patient is asked to walk along a 15-meter stretch of corridor at a pace that would make them feel tired by the end. The total distance walked in six minutes is recorded in meters. Chairs are arranged along the corridor to allow for resting if needed, though any time spent resting is counted within the six minutes. Standard motivational messages are given at each minute as per American Thoracic Society guidelines [73]. Age and gender-specific predicted distances can be calculated from the following formula:

Distance walked in six minutes $(m)=868-($ age $\times 2.9)-($ female $\times 74.7)$

where age is in years and the value "1" is assigned for females [74]. There is evidence for the validity of the $6 \mathrm{MWT}$ as a measure of recovery after colorectal surgery $[75]$.

Secondary outcomes included complication rates, self-reported physical activity and health-related quality of life. Complications were graded by severity using the Dindo-Clavien classification, in which grade I complications require 
bedside management, grade II require pharmacological treatment, and grade III and IV complications require surgical or radiological intervention, or intensive care treatment respectively [76].

Self-reported physical activity was measured by the Community Healthy Activities Model Program for Seniors (CHAMPS) short-form questionnaire. In the CHAMPS questionnaire, subjects estimate the number of hours spent performing listed activities of various intensities in the previous week. An estimate of the caloric expenditure associated with each activity is used to calculate weekly energy expenditure in kilocalories per kilogram per week. A $3 \mathrm{kcal} / \mathrm{kg} /$ week difference is equivalent to 1 hour of moderate intensity activity [77]. Available evidence supports the validity of the CHAMPS questionnaire as a measure of recovery of physical activity after elective surgery [78].

Health-related quality of life was measured using the Medical Outcomes Study 36-Item Short-Form Health Survey (SF-36). This survey assesses eight domains of health including physical function, role physical, role emotional, social functioning, bodily pain, general health, vitality, and mental health. Each domain is assessed on a 0-100 scale, with higher scores indicating better quality of life. Two summary scores- the physical component summary (PCS) and mental component summary (MCS)- have been standardized to have a mean of 50 and standard deviation of 10 . Canadian population norms are available [79].

Emotional health was measured using the Hospital Anxiety and Depression Scale (HADS) for patients undergoing the prehabilitation intervention. HADS contains 7 items each scored from 0 to 3 points for anxiety and for depression. 
It provides summary measures on a $0-21$ scale, with scores over 8 suggesting the presence of a mood disorder [80].

\subsubsection{Statistical methods}

To minimize potential bias from missing data ( 8 week $6 \mathrm{MWT}$ was missing in 5 patients in prehab group), multiple imputation was performed. Twenty imputations were created based on age, gender, comorbidities, complication profile, 6MWT results, and CHAMPS and SF-36 responses [81]. Functional data is presented as an aggregate of all imputations taking into account variance between and within imputations using Rubin's rules. Continuous variables modeled by a normal distribution were reported as mean $\pm \mathrm{SD}$ and compared using an independent Student's t-test. Non-normal data was reported as median [IQR] and compared using a non-parametric Wilcoxon rank-sum test. Categorical variables were compared using Pearson's $\chi^{2}$ test or Fisher's exact test. We used 20 meters, considered to be the error of measurement of the 6MWT in the elderly population to categorize change [82]. If a patient's 6MWT was within 20 meters of their previous result, this change was not considered to be clinically meaningful. Multiple linear regression was used on imputed data to evaluate the predictors of recovery of functional walking capacity at 8 weeks postop. Standard errors accounted for variance both between and within imputations. A probability level less than 0.05 was considered significant. Statistical analyses were conducted using $\mathrm{R}$ version 2.14 (R Foundation, Vienna, Austria). Multiple imputation and analysis were performed using the Amelia II and Zelig packages respectively [83,84]. 


\subsection{Results}

Fifty-two patients were assessed for eligibility for prehabilitation: Five declined participation and 1 did not have sufficient time for prehabilitation before surgery. Of the remaining 46 patients enrolled in the prehabilitation intervention, 3 did not have any postoperative visits and 1 had benign disease on final pathology. A total of 42 patients were thus analyzed in the prehabilitation group and were compared to the control group of 45 patients. Five patients in the prehabilitation group were lost to follow-up at 8 weeks after the operation. There were no significant differences between patients who had missing data and those who did not with respects to baseline and operative characteristics, complications, or functional data (data not shown). The prehab and control groups were similar at

first assessment with respect to age, gender, body mass index, American Society of Anesthesiologist classification, and location of tumour. There were no differences with respect to functional walking capacity and self-reported physical activity levels at enrolment into the study (Table 3-1).

In the intervention group, the median duration of prehabilitation was 33 [21$46]$ days. At the end of this period, 6MWT increased by $42 \pm 41$ meters $(p<0.01)$ and self-reported weekly physical activity energy expenditure increased by a median 14 kilocalories per kilogram $(p<0.01)$. Moreover, no patient deteriorated during the prehabilitation period and $64 \%$ of patients improved by more than 20 meters. Serum albumin was measured in 17 patients and remained stable during the prehabilitation period $(3.9 \pm 0.5 \mathrm{~g} / \mathrm{dL}$ to $3.8 \pm 0.4 \mathrm{~g} / \mathrm{dL}$, mean change of $-0.15 \pm 0.3 \mathrm{~g} / \mathrm{dL}, p=0.08)$. Symptoms of anxiety and depression also decreased 
Table 3-1: Patient characteristics at study enrolment

\begin{tabular}{|c|c|c|c|}
\hline & Control $(\mathrm{n}=45)^{\mathrm{a}}$ & Prehabilitation $(n=42)^{a}$ & $\mathrm{p}$-value ${ }^{\mathrm{b}}$ \\
\hline Age, years & $66.4 \pm 12$ & $67.4 \pm 11$ & 0.69 \\
\hline Male gender & $22(64 \%)$ & $22(54 \%)$ & 0.35 \\
\hline ASA class & & & 0.59 \\
\hline I & $6(13 \%)$ & $3(7 \%)$ & \\
\hline II & $29(65 \%)$ & $31(74 \%)$ & \\
\hline III & $10(22 \%)$ & $8(19 \%)$ & \\
\hline $\mathrm{BMI}$ at first assessment, $\mathrm{kg} / \mathrm{m}^{2}$ & $26.9 \pm 6$ & $27.5 \pm 4$ & 0.61 \\
\hline 6-minute walk test, $m$ & $402 \pm 57$ & $422 \pm 87$ & 0.21 \\
\hline 6-minute walk test, $\%$ predicted & $62 \pm 9$ & $66 \pm 12$ & 0.10 \\
\hline Self-reported physical activity, & & & \\
\hline $\mathrm{kcal} / \mathrm{kg} /$ week & $20[9-32]$ & $16[10-36]$ & 0.79 \\
\hline \multicolumn{4}{|l|}{ SF-36 questionnaire: } \\
\hline Physical function & $80 \pm 24$ & $82 \pm 21$ & 0.61 \\
\hline Role physical & $58 \pm 43$ & $71 \pm 42$ & 0.18 \\
\hline Bodily pain & $78 \pm 29$ & $78 \pm 24$ & 0.99 \\
\hline General health & $69 \pm 24$ & $72 \pm 17$ & 0.47 \\
\hline Vitality & $59 \pm 23$ & $64 \pm 21$ & 0.27 \\
\hline Social function & $69 \pm 44$ & $88 \pm 25$ & 0.01 \\
\hline Role emotional & $72 \pm 26$ & $83 \pm 19$ & 0.03 \\
\hline Mental health & $70 \pm 23$ & $77 \pm 17$ & 0.13 \\
\hline Physical component summary & $47 \pm 11$ & $47 \pm 10$ & 0.93 \\
\hline Mental component summary & $45 \pm 14$ & $51 \pm 10$ & 0.01 \\
\hline HADS-Anxiety score & & $5[3-9]$ & \\
\hline HADS-Depression score & & $3[1-4]$ & \\
\hline
\end{tabular}

${ }^{\text {a }}$ Data expressed as mean $\pm \mathrm{SD}, \mathrm{N}(\%)$, or median[IQR]

b Independent Student's $t$ test or Fisher's exact test or Wilcoxon's rank-sum test as appropriate 
significantly by a median of 1 point during prehabilitation $(p=0.04$ for anxiety and $p<0.014$ for depressive symptoms). The control group was only assessed immediately prior to surgery so changes during the preoperative period could not be assessed.

Perioperative variables are presented in Table 3-2. The most frequent operation was anterior or low anterior resection. The use of laparoscopy was routine both in the control and intervention groups (93\% and $81 \%$ ). The proportion of patients receiving a stoma was similar between groups (44\% and 36\%). There were no differences in incidence or severity of postoperative complications. The overall morbidity rate was $44 \%$ and $36 \%$ respectively, and very few were classified as grade III ( $2 \%$ and $5 \%$ ). Median hospital length of stay was 4 days in both groups.

During the period of postoperative recovery, functional exercise capacity (6MWT) and self-reported physical activity were higher in the prehabilitation group compared to the control group, both at four weeks and eight weeks after surgery (Table 3-3). The trajectory of change of functional walking capacity is illustrated in Figure 3-2 demonstrating its preservation in the prehabilitation group. While patients in the intervention group were on average back to baseline by 4 weeks postoperatively ( $p=0.21$ ), the control group remained below their preoperative level $(p<0.01)$. Moreover, at 8 weeks postoperative, patients who had undergone prehabilitation were $37 \pm 70$ meters $(p<0.01)$ above their baseline values in functional walking capacity and $10 \pm 48 \mathrm{kcal} / \mathrm{kg} /$ week $(p=0.174)$ above baseline self-reported physical activity levels. A significantly greater proportion of prehabilitated patients were recovered or above baseline at 8 weeks $(81 \%)$ 
Table 3-2: Surgical information and outcomes

\begin{tabular}{|c|c|c|c|}
\hline & Control $(\mathrm{n}=45)^{\mathrm{a}}$ & Prehabilitation $(\mathrm{n}=42)^{\mathrm{a}}$ & $\mathrm{p}$-value ${ }^{\mathrm{b}}$ \\
\hline Surgery type, & & & 0.64 \\
\hline Right hemicolectomy & $9(20 \%)$ & $12(28 \%)$ & \\
\hline Left hemicolectomy & $1(2 \%)$ & $2(5 \%)$ & \\
\hline Transverse colectomy & $1(2 \%)$ & 0 & \\
\hline Sigmoidectomy & $3(7 \%)$ & $5(12 \%)$ & \\
\hline Anterior resection & $11(24 \%)$ & $5(12 \%)$ & \\
\hline Low anterior resection & $17(38 \%)$ & $15(36 \%)$ & \\
\hline Abdominoperineal resection & $3(7 \%)$ & $3(7 \%)$ & \\
\hline Stoma & $20(44 \%)$ & $15(36 \%)$ & 0.54 \\
\hline Laparoscopic approach & $42(93 \%)$ & $34(81 \%)$ & 0.11 \\
\hline Surgery duration, minutes & $215 \pm 74$ & $203 \pm 70$ & 0.45 \\
\hline Length of stay, days & $4[3-6]$ & $4[3-6]$ & 0.71 \\
\hline Complication grade, & & & 0.67 \\
\hline None & $25(56 \%)$ & $27(64 \%)$ & \\
\hline Grade I & $10(22 \%)$ & $6(14 \%)$ & \\
\hline Grade II & $9(20 \%)$ & $7(17 \%)$ & \\
\hline Grade III & $1(2 \%)$ & $2(5 \%)$ & \\
\hline
\end{tabular}

${ }^{\text {a }}$ Data expressed as mean $\pm \mathrm{SD}, \mathrm{N}(\%)$, or median[IQR]

b Independent Student's $t$ test or Fisher's exact test or Wilcoxon's rank-sum test as appropriate 
compared with controls (40\%) (Figure 4). A post-hoc power analysis looking at the change in functional walking capacity from first assessment to 8 weeks postoperative resulted in a power of 0.99 .

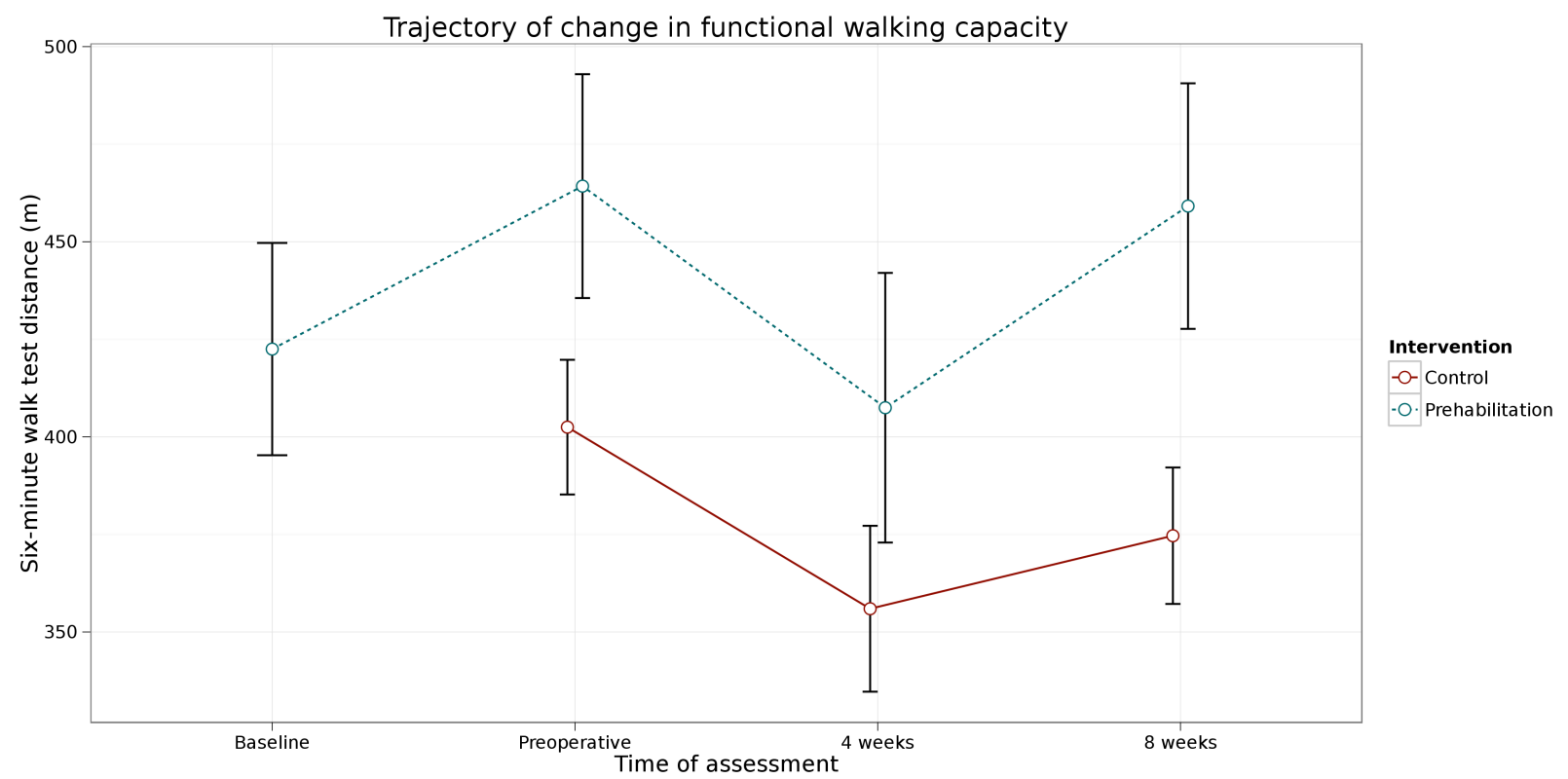

Figure 3-2: Trajectory of change in functional walking capacity as measured by the 6-minute walk test. Mean and 95\% confidence interval are displayed.

Health-related quality of life (HRQL) is presented in Table 3-4. General health, vitality, and mental health scores were higher in the prehabilitation group throughout the length of the study, including at enrolment. The prehabilitation intervention did not result in any clinically or statistically significant increases in any domains of health-related quality of life. 
Table 3-3: Functional outcomes (imputed data)

$$
\text { Control }(\mathrm{n}=45)^{\mathrm{a}} \text { Prehabilitation }(\mathrm{n}=42)^{\mathrm{ab}} \mathrm{p}^{\text {-value }}{ }^{\mathrm{c}}
$$

Six-minute walk test, $m$

Baseline

$\begin{array}{lll} & 422 \pm 87 & 0.21^{\mathrm{d}} \\ 402 \pm 57 & 464 \pm 92 & <0.01 \\ 356 \pm 71 & 407 \pm 111 & 0.01 \\ 375 \pm 58 & 459 \pm 101 & <0.01\end{array}$

Preoperative

4 weeks postoperative

$459 \pm 101$

Self-reported physical activity, $\mathrm{kcal} / \mathrm{kg} /$ week

Baseline

Preoperative

20 [9-32]

$17[10-36]$

$0.69^{\mathrm{d}}$

4 weeks postoperative

$3[0-7]$

$36[19-74]$

$<0.01$

8 weeks postoperative

$8[0-30]$

18 [8-55]

$<0.01$

$23[11-52]$

$<0.01$

HADS-Anxiety score

Baseline

Preoperative

$5[2.3-8.8]$

4 weeks postoperative

$4[2-6]$

3 [0-6.8]

8 weeks postoperative

HADS-Depression score

Baseline

Preoperative

$4[1-7]$

4 weeks postoperative

$2.5[1-4]$

1 [0-2]

$2[1-3.8]$

8 weeks postoperative

${ }^{\text {a }}$ Data expressed as mean $\pm \mathrm{SD}, \mathrm{N}(\%)$, or median[IQR]

b Owing to missing data, the number of observations ranges from 37 to 42

c Independent Student's $t$ test or Wilcoxon's rank-sum test as appropriate

${ }^{\mathrm{d}}$ Compared to the first (preoperative) assessment in the control group 


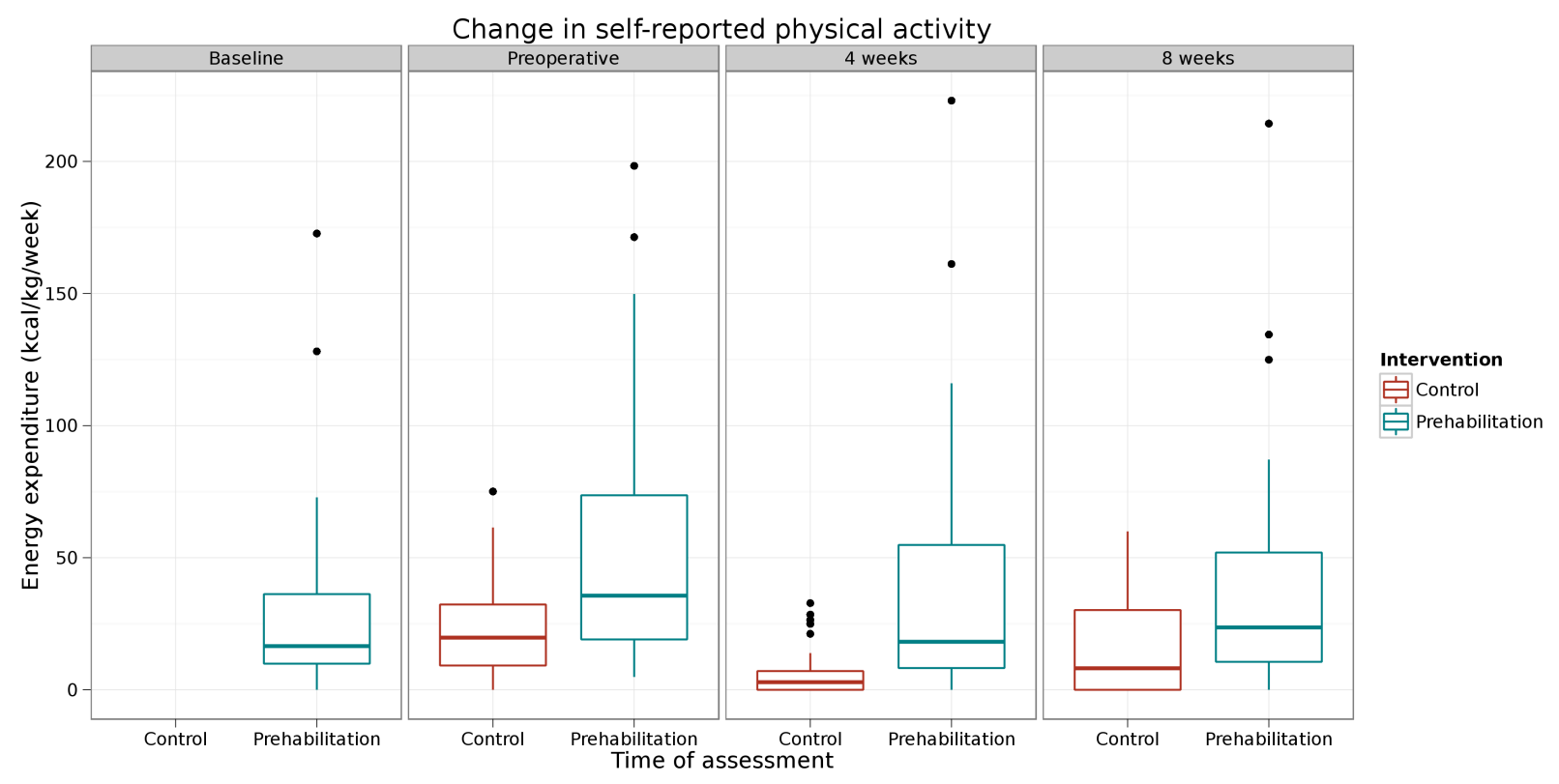

Figure 3-3: Change in self-reported physical activity as measured by the CHAMPS questionnaire. Median and quartiles are displayed.

Table 3-4: Health-related quality of life as measured by the SF-36 (imputed data)

\begin{tabular}{lllll}
\hline Component & Norms $^{2}$ & Control $^{\text {ab }}$ & Prehabilitation $^{\text {ac }}$ & p-value $^{\mathrm{d}}$ \\
\hline Physical function & 75.7 & & & \\
$\quad$ Baseline & & $82 \pm 21$ & $0.61^{\mathrm{e}}$ \\
$\quad$ Preoperative & & $80 \pm 24$ & $80 \pm 22$ & 0.94 \\
4 weeks postop. & & $70 \pm 28$ & $64 \pm 29$ & 0.32 \\
8 weeks postop. & $71 \pm 31$ & $73 \pm 25$ & 0.76 \\
Role physical & 76.2 & & & \\
Baseline & & $58 \pm 43$ & $74 \pm 38$ & 0.18 \\
Preoperative & & $37 \pm 43$ & $37 \pm 43$ & 0.07 \\
4 weeks postop. & & $58 \pm 40$ & $58 \pm 40$ & 0.92 \\
8 weeks postop. & & & 0.99 \\
\hline
\end{tabular}


Table 3-4: (continued)

\begin{tabular}{|c|c|c|c|c|}
\hline Component & Norms & Control $^{\mathrm{ab}}$ & Prehabilitation $^{\mathrm{ac}}$ & p-value \\
\hline Bodily pain & 74.0 & & & \\
\hline Baseline & & & $78 \pm 24$ & 0.99 \\
\hline Preoperative & & $78 \pm 29$ & $77 \pm 23$ & 0.81 \\
\hline 4 weeks postop. & & $59 \pm 24$ & $67 \pm 22$ & 0.11 \\
\hline 8 weeks postop. & & $72 \pm 24$ & $75 \pm 24$ & 0.55 \\
\hline General health & 73.5 & & & \\
\hline Baseline & & & $72 \pm 17$ & 0.47 \\
\hline Preoperative & & $69 \pm 24$ & $75 \pm 16$ & 0.16 \\
\hline 4 weeks postop. & & $65 \pm 20$ & $75 \pm 18$ & 0.02 \\
\hline 8 weeks postop. & & $66 \pm 18$ & $69 \pm 17$ & 0.49 \\
\hline Vitality & 67.7 & & & \\
\hline Baseline & & & $64 \pm 21$ & 0.27 \\
\hline Preoperative & & $59 \pm 23$ & $68 \pm 20$ & 0.05 \\
\hline 4 weeks postop. & & $54 \pm 22$ & $61 \pm 19$ & 0.11 \\
\hline 8 weeks postop. & & $58 \pm 21$ & $65 \pm 17$ & 0.09 \\
\hline Social function & 87.0 & & & \\
\hline Baseline & & & $88 \pm 25$ & 0.01 \\
\hline Preoperative & & $69 \pm 44$ & $84 \pm 27$ & 0.06 \\
\hline 4 weeks postop. & & $59 \pm 47$ & $59 \pm 46$ & 0.98 \\
\hline 8 weeks postop. & & $75 \pm 38$ & $75 \pm 36$ & 0.93 \\
\hline Role emotional & 80.3 & & & \\
\hline Baseline & & & $83 \pm 19$ & 0.03 \\
\hline Preoperative & & $72 \pm 26$ & $82 \pm 21$ & 0.07 \\
\hline 4 weeks postop. & & $63 \pm 32$ & $72 \pm 26$ & 0.14 \\
\hline 8 weeks postop. & & $71 \pm 28$ & $79 \pm 18$ & 0.04 \\
\hline Mental Health & 79.4 & & & \\
\hline Baseline & & & $77 \pm 17$ & 0.93 \\
\hline Preoperative & & $70 \pm 23$ & $77 \pm 18$ & 0.17 \\
\hline 4 weeks postop. & & $69 \pm 23$ & $76 \pm 18$ & 0.11 \\
\hline 8 weeks postop. & & $70 \pm 21$ & $79 \pm 18$ & 0.04 \\
\hline
\end{tabular}


Table 3-4: (continued)

\begin{tabular}{lllll}
\hline Component & Norms & Control $^{\text {ab }}$ & Prehabilitation $^{\text {ac }}$ & p-value $^{\mathrm{d}}$ \\
\hline Physical Component Summary & 50 & & & \\
$\quad$ Baseline & & $47 \pm 10$ & 0.93 \\
$\quad$ Preoperative & & $47 \pm 11$ & $48 \pm 8$ & 0.69 \\
$\quad 4$ weeks postop. & & $40 \pm 9$ & $40 \pm 8$ & 0.95 \\
$\quad 8$ weeks postop. & 50 & & & 0.99 \\
Mental Component Summary & & $51 \pm \pm 11$ & \\
$\quad$ Baseline & & $45 \pm 14$ & $50 \pm 10$ & 0.01 \\
Preoperative & & $44 \pm 14$ & $48 \pm 13$ & 0.02 \\
$\quad 4$ weeks postop. & & $46 \pm 11$ & $51 \pm 10$ & 0.12 \\
8 weeks postop. & & & 0.05 \\
\hline
\end{tabular}

\footnotetext{
a Data expressed as mean \pm SD

c The number of observations ranges from 41 to 45

b The number of observations ranges from 37 to 42

d Independent Student's $t$ test

e Compared to the first (preoperative) assessment in the control group
}

A fully adjusted multiple linear regression analysis was done on imputed data using the change in six-minute walk test from the enrolment in the study to the last evaluation as a measure of recovery from surgery (Table 3-5). After adjusting for a priori factors age, gender, body mass index, ASA classification, the use of a stoma, a low mental component summary score, and the presence of complications, the prehabilitation intervention remained a significant predictor of a positive change in functional capacity (average $+64 \mathrm{~m}, p<0.01$ ). As expected, patients with complications of grade II $(-29 \mathrm{~m}, p=0.07)$ and of grade III $(-96 \mathrm{~m}, p=0.02)$ had poorer functional recovery. A simplified model was selected using Bayesian 


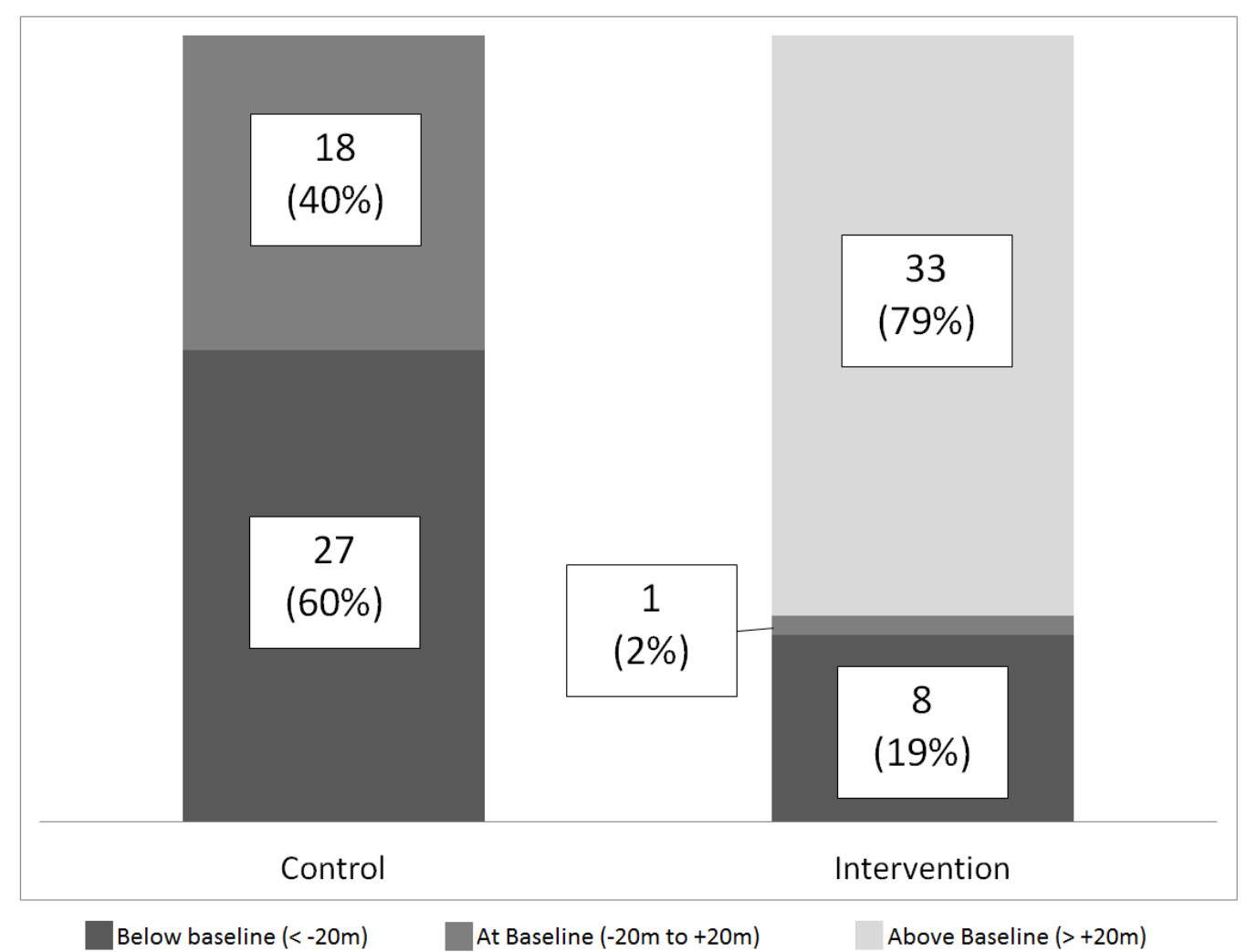

Figure 3-4: Proportion of patients having recovered to baseline functional walking capacity at 8 weeks after surgery. Patients are divided into the following groups: below baseline $(<-20 \mathrm{~m})$, at baseline $(-20 \mathrm{~m}$ to $+20 \mathrm{~m})$, and above baseline $(>+20 \mathrm{~m})$.

Information Criteria with no difference in point estimates compared to the fully adjusted model.

\subsection{Discussion}

The goal of prehabilitation is to enhance the functional capacity of patients during the waiting period for surgery. In the present study, a trimodal prehabilitation program consisting of moderate intensity physical exercise supported with nutritional supplementation and with anxiety reduction techniques resulted in a 
Table 3-5: Fully adjusted and simplified models showing significant factors influencing recovery of functional walking capacity from first to last assessment (imputed data)

\begin{tabular}{lrrrrr}
\hline & \multicolumn{2}{c}{ Model $1^{\mathrm{a}}$} & & \multicolumn{2}{c}{ Model $2^{\mathrm{b}}$} \\
\cline { 2 - 3 } \cline { 5 - 6 } Variable & \multicolumn{1}{c}{$\beta$} & $95 \% \mathrm{CI}^{\mathrm{c}}$ & & $\beta$ & $95 \% \mathrm{CI}^{\mathrm{c}}$ \\
\hline Intercept & -31.9 & $-78.2,14.4$ & & -20.1 & $-35.8,-4.5$ \\
Prehabilitation vs controls & 63.6 & $39.5,87.7$ & & 65.5 & $43.5,87.5$ \\
Complication (Clavien & & & & & \\
grade) vs 0 or I & & & & & \\
$\quad$ Grade II & -28.5 & $-59.2,2.1$ & & -27.7 & $-55.0,-0.4$ \\
$\quad$ Grade III & -95.6 & $-156.8,-34.4$ & & -97.7 & $-155.7,-39.8$ \\
\hline
\end{tabular}

a Adjusted for other variables in the table and the following nonsignificant prognostic variables: Age (referent is $<75$ years; $>=75$ years $26 \%, \beta=-2.4$, CI $=-30.8,26.0$ ), gender (referent is female; male $59 \%$, $\beta=-1.2$, CI $=-23.5,25.9$ ), body mass index (referent is $<30 \mathrm{~kg} / \mathrm{m}^{2}$; $>=30 \mathrm{~kg} / \mathrm{m}^{2} 65 \%, \beta=-8.0, \mathrm{CI}=-33.6,17.7$ ), stoma (referent is no stoma; stoma $40 \%, \beta=-9.0, \mathrm{CI}=-33.3,15.4)$, and SF-36 mental component summary (referent is $>=50 ;<5045 \%, \beta=9.0, \mathrm{CI}=$ $-15.9,33.9)$

b Simplified model selected according to Bayesian Information Criteria and adjusting only for other variables in the table

c Confidence intervals are representative of variance within each imputation and between all imputations 
significant improvement in functional walking capacity in the intervention group; $64 \%$ improved by more than 20 meters and no patients deteriorated while awaiting surgery. This improvement was associated with faster postoperative recovery in the intervention group compared the control group, with the great majority $(81 \%)$ of patients having recovered by 8 weeks after surgery compared with only $40 \%$ recovered in the control group. In a previous trial, despite an exercise-alone intervention, functional exercise capacity improved in only $33 \%$ and actually decreased in $29 \%$ of patients during the prehabilitation period [26].

In multivariate analysis, after adjusting for other confounders, we found that a benefit of 64 meters was independently attributable to participation in the trimodal prehabilitation program, a change equivalent to approximately $15 \%$ of the mean functional walking capacity at baseline. It is unclear whether this represents a clinically relevant change as there is no information on the minimal clinically important difference in 6MWT for surgical patients. However, in cardiopulmonary disease and in geriatric populations, a change of 50 meters on the $6 \mathrm{MWT}$ is seen as clinically meaningful $[85,86]$.

Health-related quality of life measures were similar at first assessment between groups except for the role emotional and social function components. This may be explained by the fact that the questionnaire was based on a 4 week recall and the values for the prehabilitation group were taken just after meeting with the colorectal surgeon, whereas the values for the control group were taken immediately preoperatively. In the 4 weeks before meeting the colorectal surgeon, patients usually lead a relatively normal life whereas in the 4 weeks coming up 
to a planned surgery, social and emotional function may be impaired. Patients tended to report better role physical and more feelings of vitality upon completion of prehabilitation. However, the prehabilitation intervention itself did not result in significant changes in quality of life between baseline and preoperative values and groups were comparable during the recovery phase. Quality of life may be too general a concept and the SF-36 questionnaire too generic to capture changes related specifically to our prehabilitation intervention.

The length of the prehabilitation period was the time from the first visit to the colorectal surgeon to the date of operation and was about one month. There was no influence of the prehabilitation program on timing of surgery, and no attempt to tailor the length of prehabilitation. The Canadian Society for Surgical Oncology recommends initiating treatment, including surgery, within two weeks of diagnosis [87]. In the last decade in Canada and in the United States, wait times for colon cancer surgery have increased and are likely to continue to rise due to increased volumes and specialization of care $[88,89]$. Although there is little evidence that longer wait times directly impact surgical outcomes, patients waiting for surgery do experience heightened levels of anxiety and frustration [54]. Exercise is associated with a reduction in anxiety and depression levels [90]. The inclusion of a psychological intervention focusing on stress reduction was chosen in this study as it can also reduce anxiety levels during this emotionally difficult period.

Complications after surgery are related to a combination of surgical, systems and patient factors. With an aging population, the comorbidities and characteristics of patients at the time of surgery pose significant challenges for quality 
improvement. Preoperative physical condition has been associated with postoperative complications [34]. In patients with cardiopulmonary disease, a 6MWT less than 350 meters predicts mortality [85]. In colorectal surgery patients, we found that a baseline $6 \mathrm{MWT}$ below $392 \mathrm{~m}$ predicts cardiopulmonary complications (unpublished data). However, unlike most other comorbidities, poor preoperative physical condition is a potentially modifiable risk factor and is the main target for a prehabilitation intervention. In the present study where all adult patients with colorectal cancer were eligible and patients with poor baseline physical capacity were not specifically targeted, the rate of major complications was relatively low and equal between the two groups. Whether targeting prehabilitation interventions specifically to patients with poor baseline functional walking capacity could prevent complications is an attractive hypothesis that remains to be investigated.

It is not clear which component of the trimodal prehabilitation program had the largest effect on enhancing functional capacity. It is, however, clear to us that a program based on exercise alone cannot be sufficient if other factors such as nutritional and psychological care are not taken into account, if only to support compliance and effectiveness of the exercise program. We previously reported limited impact of an intensive biking intervention on functional capacity. Only 16 percent of patients were fully compliant with the intensive biking intervention. Patients, especially the frail and elderly, may have been intimidated by the physical demands of the program or found the program to be too difficult [26]. With this in mind, we were more moderate with recommended exercise intensity and decreased the frequency of aerobic exercise from daily to three times per 
week. We also allowed patients to choose their preferred type of exercise, which may also have reinforced compliance by encouraging them to perform an exercise they already find enjoyable. From weekly phone call logs, about $70 \%$ of patients reported exercising at least two days a week, with $45 \%$ reporting full compliance during the prehabilitation period. There was also a significant increase in selfreported physical activity that persisted after the surgery. The exercise component may be an important adjunct to an enhanced recovery pathway where early ambulation is thought to play an important role.

In the current study, the goal of the nutritional component was to provide optimal protein intake in the context of an exercise regimen by supplementing their diet with whey-protein. Study patients did not show clinical signs of malnutrition when assessed by nutritional history, and the average albumin levels when available were normal at baseline and did not change during the prehabilitation period. Given the gains seen in functional walking capacity, the addition of nutritional management and supplementation to exercise may have helped patients to secure the adequate protein substrate for building muscle mass.

The preoperative period is a time of uncertainty for patients who often must face the unknown of both cancer and surgery [54]. Presence of preoperative psychological distress may negatively impact surgical recovery $[57,59]$. Increased physical exercise has been associated with an improvement in depressive symptoms [91]. During the prehabilitation period, patients showed a one point drop in both the anxiety and depression scores on the HADS questionnaire. This drop, though statistically significant, may not represent a large enough difference to 
impact clinical symptoms. A single one hour and a half session with a psychologist would not be sufficient to begin psychological therapy. It rather allowed patients to gain the tools to take control of anxious or stressful moments they could have felt at home. The addition of this psychological component also served to reinforce the importance of participation and was likely a factor in boosting compliance to the physical exercise component. There is little literature currently on preoperative psychological preparation by using anxiety reduction exercises. However, we believe these exercises may be useful in allaying psychological distress by providing the patients with strategies to deal with the stressful preoperative period.

There are several strengths to the study, including the use of an enhanced recovery pathway in all patients to minimize differences in perioperative care. A strength of the analysis was appropriate handling of missing data using multiple imputations, rather than excluding observations with missing data, which decreases statistical power and may result in biased estimates of effect. There are also several important limitations to our study. First, this is an observational study and allocation to group was not randomized. Also, while the intervention group were enrolled directly from the colorectal clinic when the decision for surgery was made and then reassessed immediately before surgery, the control group was enrolled in the preoperative clinic in the week preceding surgery and only had one preoperative assessment. For the purposes of this study, we have assumed that functional capacity did not change for control group patients during the wait time. 
Having this additional measure would have made baseline comparisons more accurate and would have enabled better quantification of the trajectory of functional capacity outcomes for untreated patients as they wait for surgery.

To conclude, a short period of trimodal prehabilitation comprising moderate aerobic and resistance exercise, whey-protein supplementation, and anxiety reduction improved functional walking capacity and was associated with better postoperative recovery in patients undergoing colorectal cancer surgery. 


\section{CHAPTER 4}

\section{DISCUSSION}

\subsection{Improvement During Prehabilitation Phase}

First of all, one of the aims of this pilot trial was to investigate the feasibility and effect of a new, expanded prehabilitation intervention and its effect during the prehabilitation period on functional walking capacity. We have found that by combining moderate exercise with whey protein supplementation and anxiety reduction strategies, functional walking capacity was improved on average by 42 meters. Moreover, $64 \%$ of patients saw an increase of more than 20 meters and no patient in the entire prehabilitation group deteriorated by more than 20 meters during the prehabilitation period.

These findings are in stark contrast with the limited existing knowledge in the literature. Our previous exercise-only trial found that the average change during the prehabilitation phase for the intervention (biking) group was -10.6 meters and for the control (walking/breathing) group, +8.7 meters. Moreover, respectively $42 \%$ and $19 \%$ of patients had deteriorated during this time period [26]. Similarly, in Dronkers et al., despite scheduled biweekly outpatient training in the intervention group, the training program was not found to have significant impact on both Timed-Up-and-Go and chair rise time, which are measures of functional ability. Physical work capacity was also unchanged as measured by cycle

ergometry from $29.4 \pm 9.5 \mathrm{ml} / \mathrm{kg} / \mathrm{min}$ to $27.6 \pm 6.5 \mathrm{ml} / \mathrm{kg} / \mathrm{min}$ [37]. Thus, overall, 
the two previous interventions to improve functional capacity prior to abdominal surgery have been unsuccessful at achieving their goals and have produced either mixed or negative results.

Some differences exist between the interventions given in the previous literature and our own trimodal intervention. The most important difference is the change from an exercise-only training model to a multi-modality patient-centered approach. While previous trials have focused on the effects of exercise alone, we have combined exercise with nutritional supplementation and psychological counseling, both of which were designed to support and enhance the effects of exercise. Whey protein supplementation was added, for example, to better provide protein stores for exercise and to enable greater strength and muscle gain. Our psychological intervention was based on reducing anxiety, which was a significant predictor of lessened postoperative recovery, and on improving compliance to exercise, which was a major problem in our previous trial [27]. We were therefore able to improve full compliance from $16 \%$ in the intensive biking program to $45 \%$ for our moderate walking program, which no doubt has had a positive impact on our results.

Another issue may be the measurement of functional capacity that was used in these previous trials. We used as outcome the Six-minute walk test, which is a test of submaximal walking capacity. However, the intervention arm of this previous trial trained patients on a stationary bicycle, and the skills that were learned on the bicycle may not have transferred to a walking test [26]. Similarly, the aerobic capacity was measured by cycle ergometry in Dronkers et al. though the exercise specified for patients to do at home was either walking or cycling. It 
is possible that patients who did not have access to specific equipment for cycling would not have been able to practice under the same conditions as the cycling tests they were to undergo [37]. In the current trial, the aerobic exercise that was suggested was to walk either outside or in a mall. This exercise, first of all, was more moderate in nature and started at $50 \%$ of maximal heart rate, which allows patients to derive pleasure from participation and improved their compliance. The previous intense biking exercise may have been to intense for a more frail, elderly cancer population. Furthermore, training by walking allowed patients to directly practice the skill they were required to demonstrate during performance of the Six-minute walk test.

Moreover, due to our before and after study design, we did not recruit patients at the colorectal clinic for our control group for baseline evaluation and thus were unable to determine the change in functional capacity while waiting for surgery. From our previous trial, however, we know that patients, regardless of whether they received the biking or the "sham" walking/breathing intervention, were likely to either stay at baseline levels or deteriorate [26, 27]. Comparatively, during the preoperative period, no recommendations for exercise are given as standard of care. Given that exercise theoretically improves or at least mitigates the deterioration in functional capacity, the most likely trend for patients waiting for colorectal cancer surgery would be to stay the same or to deteriorate.

\subsection{Prehabilitation and Postoperative Recovery}

The length of hospital stay in both the prehabilitation and the control groups was a median 4 days and overall complication rates were respectively $36 \%$ and 
44\%. Very few patients had major complications (2\% and 5\% respectively) as classified by a Clavien grade above III. These numbers are comparable with a recent review of 297 scheduled laparoscopic colectomies performed at our centre, which has also shown a median length of stay of 4 days and complication rates hovering around 40\% [92]. Comparatively, our exercise-only prehabilitation trial showed average length of stays of 7.4 and 6.6 days and complication rates of $39 \%$ and $33 \%$ for the biking and "sham" groups respectively. However, major complications were more common (11\% and 6\%).

Successful improvement in functional capacity during the prehabilitation period is an attractive concept preoperatively as there have been a number of trials linking improvement in functional capacity with decrease postoperative complications $[32,34]$. We have also shown that patients that improve during prehabilitation were less at risk for postoperative complications [27]. However, we did not see a significant difference in postoperative complications between prehabilitation and control groups, though there was a raw decrease of $8 \%$. During an audit of recent $6 \mathrm{MWT}$ data, we also found that a lower $6 \mathrm{MWT}$ preoperatively were more predictive of cardiopulmonary complications rather than overall complications [36]. A reasonable interpretation is that a higher 6MWT distance translates into improved aerobic capacity. It would be unlikely to see a difference in postoperative complications that are related to surgical technique or that are of infectious nature such as anastomotic leaks, wound infections, and urinary infections in relation to improved aerobic capacity. Given the nature of colorectal cancer surgery, cardiopulmonary complications do not form the bulk of the burden 
of morbidity and this trial was not designed with sufficient power to detect such a change.

Other major differences between our current trial and previous trials include the intraoperative and perioperative care period. In the surgical realm, we have seen the adoption of laparoscopic colorectal surgery. The proportion of patients operated using a laparoscopic technique as thus increased from $24 \%$ in the previous trial to over $80 \%$ in the current trial. Perioperative care also changed such that patients now follow a enhanced recovery pathway, which eliminates variability in postoperative management and streamlines care. Enhanced recovery has been associated with shorter hospital stay and some studies have shown decreases in overall morbidity [18]. Laparoscopy also carries theoretical benefits mainly in decreasing surgical stress and postoperative pain and has been shown to reduce hospital stay when combined with enhanced recovery pathways [24]. Though it is difficult to estimate the impact of these changes on postoperative recovery, enhanced recovery pathways have enabled standardization of postoperative care which may have had differential effects of patient recovery in previous trials.

The postoperative trend in functional walking capacity, self-reported physical activity, and physical component summary all mirror the hypothesized theoretical framework of recovery and prehabilitation as described in section 1.3.1. The curve of functional walking capacity (Figure 3-2) shows, as predicted, a decrease related to the insult of surgery which is measurable at 4 weeks postoperatively and a gradual recovery during the following month. Similarly, patients report less physical activity (Figure 3-3) 4 weeks after surgery than they do prior to surgery, 
and this recovers over time back to baseline values. Physical component summary of the SF-36 shows a similar decline from 47 points at baseline to 40 points 4 weeks after surgery, with a recovery to 44 points by 8 weeks postoperatively in both groups. These trends are all compatible with the idea of surgery-induced decrease in function followed by a gradual return to normal. It is likely that at 4 weeks, patients are already on the upwards path towards recovery from the surgical insult, though the true nadir of these trajectories lies in the period immediately after surgery or within the hospital period.

Eight weeks after surgery, we found that trimodal prehabilitation resulted in patients who were on average $37 \pm 70$ meters above their baseline functional walking capacity whereas control patients were on average $28 \pm 31$ meters below. Moreover, $81 \%$ of prehabilitated patients were considered to have recovered to baseline functional walking capacity versus $40 \%$ in the control group. In our previous trial, differences from baseline at follow-up evaluation were $-28 \mathrm{~m}$ and $-7 \mathrm{~m}$ for the biking and "sham" intervention groups, with $53 \%$ and $66 \%$ considered recovered to baseline respectively. Though not immediately comparable due to sample characteristics, the timing of the evaluations were similar in the two trials. The trimodal prehabilitation intervention was the only intervention that showed an increase in the average change in functional walking capacity. The control group from the current pilot study received only standard care and did not receive any recommendations or programs. Therefore, they had worse results than the control group from the previous prehabilitation trial as the current controls did not receive any intervention or recommendation to mitigate the postoperative functional drop. 
Although our previous randomized trial was unsuccessful at showing a benefit for a stationary biking program when compared to recommendations for walking and breathing exercises, there could be some benefit to recovery in giving any recommendation for maintaining or increasing physical activity both in the preand postoperative period over standard care.

Despite improvement in functional walking capacity, patients in both our prehabilitation and control groups were still on average $4 \pm 10$ points below their baseline SF-36 physical component summary scores, which is considered just below the margin for a clinically meaningful change. Postoperative scores were especially low for the role physical subscale at $37 \pm 43$ points and $58 \pm 40$ points at 4 and 8 weeks after surgery in both groups. Questions that contribute to the role physical subscale have to do with limitation of physical activity. There are questions about easy physical activities such as dressing or taking a bath, and there are questions about difficult physical activities such as vigorous running, walking more than a mile, and climbing stairs. Although patients may find that they are able to complete a submaximal aerobic test such as the 6MWT or even have improved walking capacity on average, they may still feel limitations in difficult vigorous activities.

\subsection{Limitations}

The most important limitation in our context is the lack of a true baseline value for controls. Univariate baseline comparisons were done on data that was not collected at the same time point, which may reduce the validity of such comparisons. Moreover, when calculating the change from baseline values 
in functional walking capacity, we could not use a true baseline value for the control group as they were not assessed at this time point. To palliate this, we have assumed for our analysis that functional walking capacity would have remained unchanged while waiting for surgery. We would currently estimate that functional walking capacity is likely to stay the same or decline if no intervention is given, since our previous randomized controlled trial showed non-significant changes, including a trend for slight deterioration in the biking group and for slight improvement for the "sham" intervention group.

Secondly, the trial is designed as a before and after prospective trial. This introduces a time bias, as the control group was assessed in 2009 to 2010, and the intervention group from 2010 to 2011. There were no specific changes to perioperative or intraoperative care during these two years, though subtle changes in surgical, anesthetic, and perioperative practice as well as environmental patterns such as active life promotion in the hospital or the media may have had subtle effects on the results. Although comparison between both groups on known confounders at baseline have shown no differences, such unmeasured confounders may introduce bias. This before-and-after design also means that there was no blinding of the assessors as they knew which group the patient belonged in. Our assessments are, for the most part, considered objective (the Six-minute walk test does not, theoretically, depend on the interaction between assessor and participant) and it would have been impossible to blind the patient to his or her treatment. 
Furthermore, although the nutritional and psychological components were designed to support the exercise program, it would have been interesting to have collected more data to see the effects of these added interventions. For example, better measurement of serum albumin and of C-reactive protein could have enabled us to draw inferences on the effects of whey protein on albumin synthesis and systemic inflammation. Moreover, we could have collected additional data on body composition (fat and fat-free mass) using caliper measurements or bioelectrical impedance analysis to better delineate the effect of exercise and protein on different body components. Although we had height and weight measurements at baseline, it would also have been interesting to follow these measurements through time to see if patients who were overweight were able to lose fat, or if patients who were underweight gained muscle mass. Other dynamic measurements such as hand grip and knee extension strength could also have been used to measure improvements in muscle strength related to resistance exercise.

There is also the issue that increase in compliance may be mediating the difference in results when comparing the trimodal prehabilitation program to the previous exercise-only program. Full compliance increased from 16 percent in the exercise-only program to 45 percent in the current program. Although there is an argument that increase in compliance may have mediated increase in functional walking capacity, improving compliance is nonetheless an important goal of our new trimodal program. Though without doubt, increasing compliance to the exercise component may help improve walking capacity, motivating patients to change their lifestyle, even momentarily in preparation for surgery, can be a major 
challenge. The anxiety reduction intervention also had as a goal to reinforce the participation to the two other elements of the trimodal program. It is therefore possible that the anxiety reduction component helped in increasing the exercise performed by the patients, which in itself, is a worthwhile addition.

Finally, although we found a small decrease in the HADS anxiety and depression score during prehabilitation, we had no similar information for the control group as the HADS questionnaire had not been provided. It would also have been interesting to have either a qualitative section or a questionnaire to obtain patient satisfaction scores for the program. We did have some drop-out of patients during the follow-up period and it would have been interesting to know patients' opinions about the program itself.

\subsection{Future Considerations}

This pilot trial was designed first and foremost as a proof of concept - that we are able to use a prehabilitation intervention that successfully increases functional capacity prior to surgery. With the current information that is available, it becomes possible to plan a follow-up trial and to calculate sufficient sample sizes.

The follow-up trial would be designed as a double-arm randomized-controlled trial, with one arm undergoing the prehabilitation program as described above, and the second arm as a control group. If possible, we would blind the assessors to the patient grouping and would recruit both groups at the colorectal clinic so as to obtain true baseline values for the control group. Primary outcome would remain functional walking capacity at 8 weeks after surgery as we believe that our goal remains to find interventions that may help with patient recovery. Secondary 
outcomes would include postoperative complications, health-related quality of life, anxiety and depression questionnaires, and I would add nutritional parameters such as albumin, C-reactive protein, and patient weight at all time points.

For our sample size calculation, we can assume that we would find a similar difference at 8 weeks postoperatively between the two groups. For our current trial, the differences from baseline were respectively $+37 \pm 70 \mathrm{~m}$ in the prehabilitation group and $-28 \pm 31 \mathrm{~m}$ in the control group, which yields a mean difference of $65 \mathrm{~m}$ with a $95 \%$ confidence interval of $41 \mathrm{~m}$ to $88 \mathrm{~m}$. The calculated effect size of undergoing prehabilitation above controls is 1.20. Given a power analysis for a two-tailed two-sample independent t-test with significance level set at 0.05, a power of 0.95 and an allocation ratio of 1 to 1 , we would require a total sample of 40 patients (20 per group). Therefore, to plan a future trial, we would recruit at a minimum 20 patients per group to achieve sufficient power to detect the same difference as we have seen with our current trial. 


\section{CHAPTER 5}

CONCLUSiON

Prehabilitation interventions have classically focused on one modality alone in attempting to improve function before surgery. In the study, we have investigated the effects of a prehabilitation program which incorporated a combination of three interventions: a home-based moderate exercise program, nutritional counseling and whey protein supplementation, and a relaxation and anxiety reduction component.

We have shown an significant increase in functional walking capacity during the prehabilitation period and have thus confirmed the feasibility and effectiveness of a multimodal approach to improving functional capacity. This increase translated into better postoperative function both at 4 and 8 weeks, as predicted by our theoretical framework of recovery. Despite this, the physical component summary of health-related quality of life was not yet at baseline at 8 weeks after surgery, portraying the continued challenge and need for investigating interventions to improve recovery.

Data from this pilot trial have allowed the calculation of sample size estimates for a randomized controlled trial, which may decrease potential bias and provide us with higher levels of evidence for such a trimodal prehabilitation program. This randomized controlled trial is ongoing (NCT01356264). 


\section{LIST OF REFERENCES}

[1] Canadian Cancer Society. Canadian Cancer Statistics; 2012. https://www . cancer.ca/Canada-wide/About\%20cancer/ /media/CCS/Canada\%20wide/ Files $\% 20$ List/English $\% 20$ files $\% 20$ heading/PDF $\% 20-\% 20 \mathrm{Policy} \% 20-\%$ 20Canadian $\% 20$ Cancer $\% 20$ Statistics $\% 20-\% 20$ English/Canadian $\% 20$ Cancer $\%$ 20Statistics $\% 202012 \% 20-\% 20$ English. ashx.

[2] Center MM, Jemal A, Ward E. International trends in colorectal cancer incidence rates. Cancer Epidemiol Biomarkers Prev. 2009 Jun;18(6):16881694.

[3] Center MM, Jemal A, Smith RA, Ward E. Worldwide variations in colorectal cancer. CA Cancer J Clin. 2009;59(6):366-378.

[4] Vogelstein B, Fearon ER, Hamilton SR, Kern SE, Preisinger AC, Leppert M, et al. Genetic alterations during colorectal-tumor development. N Engl J Med. 1988 Sep;319(9):525-532.

[5] Howlader N, Noone AM, Krapcho M, Neyman N, Aminou R, Altekruse SF, Kosary CL, Ruhl J, Tatalovich Z, Cho H, Mariotto A, Eisner MP, Lewis DR, Chen HS, Feuer EJ, Cronin KA. SEER Cancer Statistics Review, 1975-2009 (Vintage 2009 Populations); 2012. http://seer.cancer.gov/csr/1975_ 2009_pops09/.

[6] Giovannucci E. Modifiable risk factors for colon cancer. Gastroenterol Clin North Am. 2002 Dec;31(4):925-943.

[7] Cappell MS. Pathophysiology, clinical presentation, and management of colon cancer. Gastroenterol Clin North Am. 2008 Mar;37(1):1-24.

[8] O'Connell JB, Maggard MA, Ko CY. Colon cancer survival rates with the new American Joint Committee on Cancer sixth edition staging. J Natl Cancer Inst. 2004 Oct;96(19):1420-1425. 
[9] Green FL, Page DL, Fleming ID, et al , editor. AJCC Cancer Staging Handbook. 6th ed. Springer, New York; 2002.

[10] McLeod RS. Screening strategies for colorectal cancer: a systematic review of the evidence. Can J Gastroenterol. 2001 Oct;15(10):647-660.

[11] Telford JJ. Canadian guidelines for colorectal cancer screening. Can J Gastroenterol. 2011 Sep;25(9):479-481.

[12] National Comprehensive Cancer Network. NCCN Guidelines Colon Cancer, Version 2.2013; 2012. http://www.nccn.org/professionals/physician_ gls/pdf/colon.pdf.

[13] National Comprehensive Cancer Network. NCCN Guidelines Rectal Cancer, Version 3.2013; 2012. http://www.nccn.org/professionals/physician_ gls/pdf/rectal.pdf.

[14] Ozhathil DK, Li Y, Smith JK, Witkowski E, Coyne ER, Alavi K, et al. Colectomy performance improvement within NSQIP 2005-2008. J Surg Res. 2011 Nov;171(1):9-13.

[15] Veldkamp R, Kuhry E, Hop WC, Jeekel J, Kazemier G, Bonjer HJ, et al. Laparoscopic surgery versus open surgery for colon cancer: short-term outcomes of a randomised trial. Lancet Oncol. 2005 Jul;6(7):477-484.

[16] Guillou PJ, Quirke P, Thorpe H, Walker J, Jayne DG, Smith AM, et al. Short-term endpoints of conventional versus laparoscopic-assisted surgery in patients with colorectal cancer (MRC CLASICC trial): multicentre, randomised controlled trial. Lancet. 2005;365(9472):1718-1726.

[17] Jayne DG, Thorpe HC, Copeland J, Quirke P, Brown JM, Guillou PJ. Five-year follow-up of the Medical Research Council CLASICC trial of laparoscopically assisted versus open surgery for colorectal cancer. Br J Surg. 2010 Nov;97(11):1638-1645.

[18] Spanjersberg WR, Reurings J, Keus F, van Laarhoven CJ. Fast track surgery versus conventional recovery strategies for colorectal surgery. Cochrane Database Syst Rev. 2011;(2):CD007635.

[19] Tran T. Development of a novel measure of surgical recovery using Rasch analysis. McGill University; 2010. 
[20] Marshall SI, Chung F. Discharge criteria and complications after ambulatory surgery. Anesth Analg. 1999 Mar;88(3):508-517.

[21] Wilson IB, Cleary PD. Linking clinical variables with health-related quality of life. A conceptual model of patient outcomes. JAMA. 1995 Jan;273(1):59-65.

[22] Carli F, Mayo N, Klubien K, Schricker T, Trudel J, Belliveau P. Epidural analgesia enhances functional exercise capacity and health-related quality of life after colonic surgery: results of a randomized trial. Anesthesiology. 2002 Sep;97(3):540-549.

[23] Jensen MB, Houborg KB, Norager CB, Henriksen MG, Laurberg S. Postoperative changes in fatigue, physical function and body composition: an analysis of the amalgamated data from five randomized trials on patients undergoing colorectal surgery. Colorectal Dis. 2011 May;13(5):588-593.

[24] Vlug MS, Wind J, Hollmann MW, Ubbink DT, Cense HA, Engel AF, et al. Laparoscopy in combination with fast track multimodal management is the best perioperative strategy in patients undergoing colonic surgery: a randomized clinical trial (LAFA-study). Annals of surgery. 2011;254(6):868.

[25] Carli F, Zavorsky GS. Optimizing functional exercise capacity in the elderly surgical population. Curr Opin Clin Nutr Metab Care. 2005 Jan;8(1):23-32.

[26] Carli F, Charlebois P, Stein B, Feldman L, Zavorsky G, Kim DJ, et al. Randomized clinical trial of prehabilitation in colorectal surgery. Br J Surg. 2010 Aug;97(8):1187-1197.

[27] Mayo NE, Feldman L, Scott S, Zavorsky G, Kim doJ, Charlebois P, et al. Impact of preoperative change in physical function on postoperative recovery: argument supporting prehabilitation for colorectal surgery. Surgery. 2011 Sep;150(3):505-514.

[28] Bean JF, Vora A, Frontera WR. Benefits of exercise for community-dwelling older adults. Arch Phys Med Rehabil. 2004 Jul;85(7 Suppl 3):31-42.

[29] Nelson ME, Rejeski WJ, Blair SN, Duncan PW, Judge JO, King AC, et al. Physical activity and public health in older adults: recommendation from the American College of Sports Medicine and the American Heart Association. Med Sci Sports Exerc. 2007 Aug;39(8):1435-1445. 
[30] Colditz GA, Cannuscio CC, Frazier AL. Physical activity and reduced risk of colon cancer: implications for prevention. Cancer Causes Control. 1997 $\mathrm{Jul} ; 8(4): 649-667$.

[31] Quadrilatero J, Hoffman-Goetz L. Physical activity and colon cancer. A systematic review of potential mechanisms. J Sports Med Phys Fitness. 2003 Jun;43(2):121-138.

[32] Reilly DF, McNeely MJ, Doerner D, Greenberg DL, Staiger TO, Geist MJ, et al. Self-reported exercise tolerance and the risk of serious perioperative complications. Arch Intern Med. 1999 Oct;159(18):2185-2192.

[33] Dronkers J, Chorus A, Meeteren N, Hopman-Rock M. The association of preoperative physical fitness and physical activity with outcome after scheduled major abdominal surgery. Anaesthesia. 2012;.

[34] Wilson RJ, Davies S, Yates D, Redman J, Stone M. Impaired functional capacity is associated with all-cause mortality after major elective intraabdominal surgery. Br J Anaesth. 2010 Sep;105(3):297-303.

[35] Nutt C, Russell J. Use of the pre-operative shuttle walk test to predict morbidity and mortality after elective major colorectal surgery. Anaesthesia. 2012 ;

[36] Lee L. Six-minute walk test identifies patients at high risk for cardiopulmonary complications after colorectal resection. McGill University; 2012.

[37] Dronkers JJ, Lamberts H, Reutelingsperger IM, Naber RH, DronkersLandman CM, Veldman A, et al. Preoperative therapeutic programme for elderly patients scheduled for elective abdominal oncological surgery: a randomized controlled pilot study. Clin Rehabil. 2010 Jul;24(7):614-622.

[38] Valkenet K, van de Port IG, Dronkers JJ, de Vries WR, Lindeman E, Backx FJ. The effects of preoperative exercise therapy on postoperative outcome: a systematic review. Clin Rehabil. 2011 Feb;25(2):99-111.

[39] Jack S, West M, Grocott MP. Perioperative exercise training in elderly subjects. Best Pract Res Clin Anaesthesiol. 2011 Sep;25(3):461-472.

[40] McMillan DC. Systemic inflammation, nutritional status and survival in patients with cancer. Curr Opin Clin Nutr Metab Care. 2009 May;12(3):223226. 
[41] Garth AK, Newsome CM, Simmance N, Crowe TC. Nutritional status, nutrition practices and post-operative complications in patients with gastrointestinal cancer. J Hum Nutr Diet. 2010 Aug;23(4):393-401.

[42] Burden ST, Hill J, Shaffer JL, Todd C. Nutritional status of preoperative colorectal cancer patients. J Hum Nutr Diet. 2010 Aug;23(4):402-407.

[43] Panis Y, Maggiori L, Caranhac G, Bretagnol F, Vicaut E. Mortality after colorectal cancer surgery: a French survey of more than 84,000 patients. Ann Surg. 2011 Nov;254(5):738-743.

[44] Telem DA, Chin EH, Nguyen SQ, Divino CM. Risk factors for anastomotic leak following colorectal surgery: a case-control study. Arch Surg. 2010 Apr;145(4):371-376.

[45] Jean-Claude M, Emmanuelle P, Juliette H, Michele B, Gerard D, Eric F, et al. Clinical and economic impact of malnutrition per se on the postoperative course of colorectal cancer patients. Clin Nutr. 2012 May;.

[46] Lemon P, Tarnopolsky M, MacDougall JD, Atkinson S. Protein requirements and muscle mass/strength changes during intensive training in novice bodybuilders. Journal of Applied Physiology. 1992;73(2):767-775.

[47] Cermak NM, Res PT, de Groot LC, Saris WH, van Loon LJ. Protein supplementation augments the adaptive response of skeletal muscle to resistance-type exercise training: a meta-analysis. Am J Clin Nutr. 2012 Nov;.

[48] Tang JE, Manolakos JJ, Kujbida GW, Lysecki PJ, Moore DR, Phillips SM. Minimal whey protein with carbohydrate stimulates muscle protein synthesis following resistance exercise in trained young men. Appl Physiol Nutr Metab. 2007 Dec;32(6):1132-1138.

[49] Burke DG, Chilibeck PD, Davidson KS, Candow DG, Farthing J, SmithPalmer T. The effect of whey protein supplementation with and without creatine monohydrate combined with resistance training on lean tissue mass and muscle strength. Int J Sport Nutr Exerc Metab. 2001 Sep;11(3):349-364.

[50] Bounous G, Batist G, Gold P. Immunoenhancing property of dietary whey protein in mice: role of glutathione. Clin Invest Med. 1989 Jun;12(3):154-161.

[51] Bounous G, Batist G, Gold P. Whey proteins in cancer prevention. Cancer Lett. 1991 May;57(2):91-94. 
[52] Attaallah W, Yilmaz AM, Erdogan N, Yalcin AS, Aktan AO. Whey protein versus whey protein hydrolyzate for the protection of azoxymethane and dextran sodium sulfate induced colonic tumors in rats. Pathol Oncol Res. 2012 Oct;18(4):817-822.

[53] Hakkak R, Korourian S, Ronis MJ, Johnston JM, Badger TM. Dietary whey protein protects against azoxymethane-induced colon tumors in male rats. Cancer Epidemiol Biomarkers Prev. 2001 May;10(5):555-558.

[54] Moene M, Bergbom I, Skott C. Patients' existential situation prior to colorectal surgery. J Adv Nurs. 2006 Apr;54(2):199-207.

[55] Dunn J, Lynch B, Rinaldis M, Pakenham K, McPherson L, Owen N, et al. Dimensions of quality of life and psychosocial variables most salient to colorectal cancer patients. Psychooncology. 2006 Jan;15(1):20-30.

[56] Broadbent E, Petrie KJ, Alley PG, Booth RJ. Psychological stress impairs early wound repair following surgery. Psychosom Med. 2003;65(5):865-869.

[57] Linn BS, Linn MW, Klimas NG. Effects of psychophysical stress on surgical outcome. Psychosom Med. 1988;50(3):230-244.

[58] Kiecolt-Glaser JK, Page GG, Marucha PT, MacCallum RC, Glaser R. Psychological influences on surgical recovery: perspectives from psychoneuroimmunology. American Psychologist. 1998;53(11):1209.

[59] Mavros MN, Athanasiou S, Gkegkes ID, Polyzos KA, Peppas G, Falagas ME. Do psychological variables affect early surgical recovery? PLoS ONE. 2011;6(5):e20306.

[60] Miró J, Raich RM. Preoperative preparation for surgery: an analysis of the effects of relaxation and information provision. Clinical Psychology \& Psychotherapy. 1999;6(3):202-209.

[61] Jemal A, Bray F, Center MM, Ferlay J, Ward E, Forman D. Global cancer statistics. CA Cancer J Clin. 2011;61(2):69-90.

[62] Schilling PL, Dimick JB, Birkmeyer JD. Prioritizing quality improvement in general surgery. J Am Coll Surg. 2008 Nov;207(5):698-704. 
[63] Zingmond D, Maggard M, O’Connell J, Liu J, Etzioni D, Ko C. What predicts serious complications in colorectal cancer resection? Am Surg. 2003 Nov;69(11):969-974.

[64] Christensen T, Kehlet H. Postoperative fatigue. World J Surg. $1993 ; 17(2): 220-225$.

[65] Lawrence VA, Hazuda HP, Cornell JE, Pederson T, Bradshaw PT, Mulrow CD, et al. Functional independence after major abdominal surgery in the elderly. J Am Coll Surg. 2004 Nov;199(5):762-772.

[66] Timmerman H, de Groot JF, Hulzebos HJ, de Knikker R, Kerkkamp HE, van Meeteren NL. Feasibility and preliminary effectiveness of preoperative therapeutic exercise in patients with cancer: a pragmatic study. Physiother Theory Pract. 2011 Feb;27(2):117-124.

[67] Burd NA, Yang Y, Moore DR, Tang JE, Tarnopolsky MA, Phillips SM. Greater stimulation of myofibrillar protein synthesis with ingestion of whey protein isolate $\mathrm{v}$. micellar casein at rest and after resistance exercise in elderly men. Br J Nutr. 2012 Jan;p. 1-5.

[68] Aoi W, Takanami Y, Kawai Y, Morifuji M, Koga J, Kanegae M, et al. Dietary whey hydrolysate with exercise alters the plasma protein profile: a comprehensive protein analysis. Nutrition. 2011 Jun;27(6):687-692.

[69] Walzem RL, Dillard CJ, German JB. Whey components: millennia of evolution create functionalities for mammalian nutrition: what we know and what we may be overlooking. Crit Rev Food Sci Nutr. 2002 Jul;42(4):353-375.

[70] Marshall K. Therapeutic applications of whey protein. Altern Med Rev. 2004 Jun;9(2):136-156.

[71] Carli F, Charlebois P, Baldini G, Cachero O, Stein B. An integrated multidisciplinary approach to implementation of a fast-track program for laparoscopic colorectal surgery. Can J Anaesth. 2009 Nov;56(11):837-842.

[72] Bauer J, Capra S, Ferguson M. Use of the scored Patient-Generated Subjective Global Assessment (PG-SGA) as a nutrition assessment tool in patients with cancer. Eur J Clin Nutr. 2002 Aug;56(8):779-785.

[73] American Thoracic Society. ATS statement: guidelines for the six-minute walk test. Am J Respir Crit Care Med. 2002 Jul;166(1):111-117. 
[74] Gibbons WJ, Fruchter N, Sloan S, Levy RD. Reference values for a multiple repetition 6-minute walk test in healthy adults older than 20 years. J Cardiopulm Rehabil. 2001;21(2):87-93.

[75] Moriello C, Mayo NE, Feldman L, Carli F. Validating the six-minute walk test as a measure of recovery after elective colon resection surgery. Arch Phys Med Rehabil. 2008 Jun;89(6):1083-1089.

[76] Dindo D, Demartines N, Clavien PA. Classification of surgical complications: a new proposal with evaluation in a cohort of 6336 patients and results of a survey. Ann Surg. 2004 Aug;240(2):205-213.

[77] Ainsworth BE, Haskell WL, Herrmann SD, Meckes N, Bassett DR, TudorLocke C, et al. 2011 Compendium of Physical Activities: a second update of codes and MET values. Med Sci Sports Exerc. 2011 Aug;43(8):1575-1581.

[78] Feldman LS, Kaneva P, Demyttenaere S, Carli F, Fried GM, Mayo NE. Validation of a physical activity questionnaire (CHAMPS) as an indicator of postoperative recovery after laparoscopic cholecystectomy. Surgery. 2009 Jul;146(1):31-39.

[79] Hopman WM, Towheed T, Anastassiades T, Tenenhouse A, Poliquin S, Berger C, et al. Canadian normative data for the SF-36 health survey. Canadian Multicentre Osteoporosis Study Research Group. CMAJ. 2000 Aug;163(3):265-271.

[80] Zigmond AS, Snaith RP. The hospital anxiety and depression scale. Acta Psychiatr Scand. 1983 Jun;67(6):361-370.

[81] Graham JW, Olchowski AE, Gilreath TD. How many imputations are really needed? Some practical clarifications of multiple imputation theory. Prev Sci. 2007 Sep;8(3):206-213.

[82] Kervio G, Carre F, Ville NS. Reliability and intensity of the six-minute walk test in healthy elderly subjects. Med Sci Sports Exerc. 2003 Jan;35(1):169174 .

[83] Honaker J, King G, Blackwell M. Amelia II: A Program for Missing Data. Journal of Statistical Software. 2011;45(7):1-47.

[84] Imai K, King G, Lau O. Zelig: Everyone's Statistical Software; 2012. R package version 3.5.5. 
[85] Rasekaba T, Lee AL, Naughton MT, Williams TJ, Holland AE. The sixminute walk test: a useful metric for the cardiopulmonary patient. Intern Med J. 2009 Aug;39(8):495-501.

[86] Perera S, Mody SH, Woodman RC, Studenski SA. Meaningful change and responsiveness in common physical performance measures in older adults. J Am Geriatr Soc. 2006 May;54(5):743-749.

[87] Canadian Society of Surgical Oncology. CSSO Position Statement; http: //www.cos.ca/csso/policy.html.

[88] Simunovic M, Theriault ME, Paszat L, Coates A, Whelan T, Holowaty E, et al. Using administrative databases to measure waiting times for patients undergoing major cancer surgery in Ontario, 1993-2000. Can J Surg. 2005 Apr;48(2):137-142.

[89] Bilimoria KY, Ko CY, Tomlinson JS, Stewart AK, Talamonti MS, Hynes DL, et al. Wait times for cancer surgery in the United States: trends and predictors of delays. Ann Surg. 2011 Apr;253(4):779-785.

[90] McHugh JE, Lawlor BA. Exercise and social support are associated with psychological distress outcomes in a population of community-dwelling older adults. J Health Psychol. 2012 Sep;17(6):833-844.

[91] Rimer J, Dwan K, Lawlor DA, Greig CA, McMurdo M, Morley W, et al. Exercise for depression. Cochrane Database Syst Rev. 2012;7:CD004366.

[92] Kolozsvari NO, Capretti G, Kaneva P, Neville A, Carli F, Liberman S, et al. Impact of an enhanced recovery program on short-term outcomes after scheduled laparoscopic colon resection. Surgical Endoscopy. 2012;p. 1-6. 


\section{Appendix A: Research Instruments - Short Form 36 Questionnaire}

\section{SF-36 HEALTH STATUS SURVEY / CANADA}

Questionnaire

Date:

INSTRUCTIONS: This survey asks for your views about your health. This information will

help keep track of how you feel and how well you are able to do your usual activities.

Answer every question by marking the answer as indicated. If you are unsure about how to answer a question, please give the best answer you can.

1. In general, would you say your health is:

(circle one)

Excellent . . . . . . . . . . . . . . . . . . 1

Very good : . . . . . . . . . . . . . . . . . 2

Good... . . . . . . . . . . 3

Fair . . . . . . . . . . . . . . . . . 4

Poor . . . . . . . . . . . 5

2. Compared to one year ago, how would you rate your health in general now?

Much better now than one year ago . . . . . . . . . . . . 1

Somewhat better now than one year ago . . . . . . . . . . 2

About the same as one year ago $\quad . \quad$. . . . . . . . . . . 3

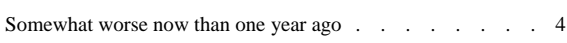

Much worse now than one year ago. . . . . . . . . . . 5

Copyright $\odot 1994$ Medical Outcomes Trust

All rights reserved.

(SF-36 Standard English-Canadian Version 1.0) 
3. The following items are about activities you might do during a typical day. Does your health now limit you in these activities? If so, how much?

(circle one number on each line)

\begin{tabular}{|c|c|c|c|}
\hline ACTIVITIES & $\begin{array}{c}\text { Yes, } \\
\text { Limited } \\
\text { A Lot }\end{array}$ & $\begin{array}{c}\text { Yes, } \\
\text { Limited } \\
\text { A Little }\end{array}$ & $\begin{array}{c}\text { No, Not } \\
\text { Limited } \\
\text { At All }\end{array}$ \\
\hline $\begin{array}{l}\text { a. Vigorous activities, such as running, lifting heavy } \\
\text { objects, participating in strenuous sports }\end{array}$ & 1 & 2 & 3 \\
\hline $\begin{array}{l}\text { b. Moderate activities, such as moving a table, pushing a } \\
\text { vacuum cleaner, bowling, or playing golf }\end{array}$ & 1 & 2 & 3 \\
\hline c. Lifting or carrying groceries & 1 & 2 & 3 \\
\hline d. Climbing several flights of stairs & 1 & 2 & 3 \\
\hline e. Climbing one flight of stairs & 1 & 2 & 3 \\
\hline f. $\quad$ Bending, kneeling, or stooping & 1 & 2 & 3 \\
\hline g. Walking more than a kilometre & 1 & 2 & 3 \\
\hline h. Walking several blocks & 1 & 2 & 3 \\
\hline i. Walking one block & 1 & 2 & 3 \\
\hline j. $\quad$ Bathing or dressing yourself & 1 & 2 & 3 \\
\hline
\end{tabular}

4. During the past 4 weeks have you had any of the following problems with your work or other regular daily activities as a result of your physical health?

(circle one number on each line)

\begin{tabular}{|c|c|c|}
\hline & YES & NO \\
\hline a. $\quad$ Cut down the amount of time you spent on work or other activities & 1 & 2 \\
\hline b. Accomplished less than you would like & 1 & 2 \\
\hline c. Were limited in the kind of work or other activities & 1 & 2 \\
\hline $\begin{array}{l}\text { d. Had difficulty performing the work or other activities (for example, it } \\
\text { took extra effort) }\end{array}$ & 1 & 2 \\
\hline
\end{tabular}


5. During the past 4 weeks, have you had any of the following problems with your work or other regular daily activities as a result of any emotional problems (such as feeling depressed or anxious)?

\begin{tabular}{|l|c|c|}
\hline & YES & NO \\
\hline a. Cut down the amount of time you spent on work or other activities & 1 & 2 \\
\hline b. Accomplished less than you would like & 1 & 2 \\
\hline c. Didn't do work or other activities as carefully as usual & 1 & 2 \\
\hline
\end{tabular}

6. During the past 4 weeks, to what extent has your physical health or emotional problems interfered with your normal social activities with family, friends, neighbors, or groups?

(circle one)
Not at all . . . . . . . . . . . . . . . 1
Slightly . . . . . . . . . . . . . . . . . . . 2
Moderately. . . . . . . . . . . . . . . . . . 3
Quite a bit . . . . . . . . . . . . . . . . 4
Extremely . . . . . . . . . . . . . . . . . . 5

7. How much bodily pain have you had during the past 4 weeks?

None . . . . . . . . . . . . . . . . . . 1

Very mild . . . . . . . . . . . . . . . . . . 2

Mild . . . . . . . . . . . . . . . . 3

Moderate . . . . . . . . . . . . . . . . . . 4

Severe . . . . . . . . . . . . . . . 5

Very severe . . . . . . . . . . . . . . . . . 6 
8. During the past 4 weeks, how much did pain interfere with your normal work (including both work outside the home and housework)?

(circle one)

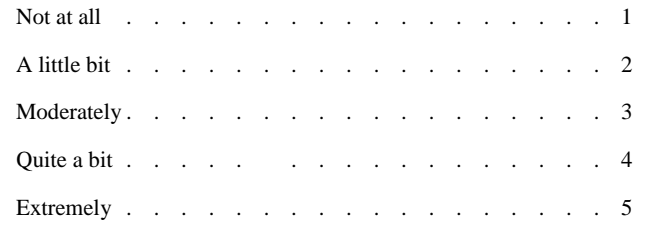

9. These questions are about how you feel and how things have been with you during the past 4 weeks. For each question, please give the one answer that comes closest to the way you have been feeling. How much of the time during the past 4 weeks

(circle one number on each line)

\begin{tabular}{|l|c|c|c|c|c|c|}
\hline & $\begin{array}{c}\text { All } \\
\text { of the } \\
\text { Time }\end{array}$ & $\begin{array}{c}\text { Most } \\
\text { of the } \\
\text { Time }\end{array}$ & $\begin{array}{c}\text { A Good } \\
\text { Bit of the } \\
\text { Time }\end{array}$ & $\begin{array}{c}\text { Some } \\
\text { of the } \\
\text { Time }\end{array}$ & $\begin{array}{c}\text { A Little } \\
\text { of the } \\
\text { Time }\end{array}$ & $\begin{array}{c}\text { None } \\
\text { of the } \\
\text { Time }\end{array}$ \\
\hline $\begin{array}{l}\text { a. Did you feel full of } \\
\text { pep? }\end{array}$ & 1 & 2 & 3 & 4 & 5 & 6 \\
\hline $\begin{array}{l}\text { b. Have you been a very } \\
\text { nervous person? }\end{array}$ & 1 & 2 & 3 & 4 & 5 & 6 \\
\hline $\begin{array}{l}\text { c. Have you felt so down } \\
\text { in the dumps that } \\
\text { nothing could cheer } \\
\text { you up? }\end{array}$ & 1 & 2 & 3 & 4 & 5 & 6 \\
\hline $\begin{array}{l}\text { d. Have you felt calm } \\
\text { and peaceful? }\end{array}$ & 1 & 2 & 3 & 4 & 5 & 6 \\
\hline $\begin{array}{l}\text { e. Did you have a lot of } \\
\text { energy? }\end{array}$ & 1 & 2 & 3 & 4 & 5 & 6 \\
\hline $\begin{array}{l}\text { f. Have you felt } \\
\text { downhearted and blue? }\end{array}$ & 1 & 2 & 3 & 4 & 5 & 6 \\
\hline g. Did you feel worn out? & 1 & 2 & 3 & 4 & 5 & 6 \\
\hline $\begin{array}{l}\text { h. Have you been a } \\
\text { happy person? }\end{array}$ & 1 & 2 & 3 & 4 & 5 & 6 \\
\hline i. Did you feel tired? & 1 & 2 & 3 & 4 & 5 & 6 \\
\hline
\end{tabular}


10. During the past 4 weeks, how much of the time has your physical health or emotional problems interfered with your social activities (like visiting with friends, relatives, etc.)?

$$
\text { (circle one) }
$$

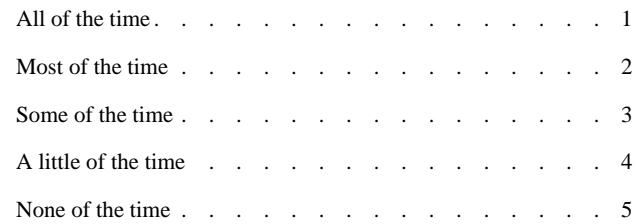

11. How TRUE or FALSE is each of the following statements for you?

(circle one number on each line)

\begin{tabular}{|c|c|c|c|c|c|}
\hline & $\begin{array}{c}\text { Definitely } \\
\text { True }\end{array}$ & $\begin{array}{c}\text { Mostly } \\
\text { True }\end{array}$ & $\begin{array}{l}\text { Don't } \\
\text { Know }\end{array}$ & $\begin{array}{l}\text { Mostly } \\
\text { False }\end{array}$ & $\begin{array}{c}\text { Definitely } \\
\text { False }\end{array}$ \\
\hline $\begin{array}{l}\text { a. I seem to get sick a little } \\
\text { easier than other people }\end{array}$ & 1 & 2 & 3 & 4 & 5 \\
\hline $\begin{array}{l}\text { b. I am as healthy as anybody I } \\
\text { know }\end{array}$ & 1 & 2 & 3 & 4 & 5 \\
\hline $\begin{array}{l}\text { c. I expect my health to get } \\
\text { worse }\end{array}$ & 1 & 2 & 3 & 4 & 5 \\
\hline d. My health is excellent & 1 & 2 & 3 & 4 & 5 \\
\hline
\end{tabular}




\title{
Appendix B: Research Instruments - CHAMPS Questionnaire
}

\author{
This questionnaire is about activities that you may have done in the past 4 weeks. The \\ questions on the following pages are similar to the example shown below. \\ INSTRUCTIONS \\ If you DID the activity in the past 2 weeks: \\ Step \#1 Check the YES box \\ Step \#2 Think about how many TIMES a week you usually did it and write your response \\ in the space provided. \\ Step \#3 Circle how many TOTAL HOURS in a tvpical week you did the activity. \\ Here is an example of how Mrs Jones would answer question \#1. Mrs Jones usually visits her \\ friends Maria and Olga twice a week. She usually spends one hour on Monday with Maria and \\ two hours on Wednesday with Olga. Therefore, the total hours a week that she visits with friends \\ is 3 hours a week. \\ In a typical week during the past 2 weeks, did you... \\ \begin{tabular}{|l|l|l|}
\hline 1. Visit with family and friends (other than & How many TOTAL hours a week did you do it? \\
\cline { 2 - 3 } & Less
\end{tabular}

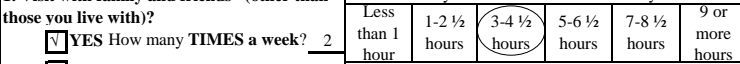 \\ $\square$ No \\ If you did not do the activity: \\ Check the NO box and move to the next question
}




\begin{tabular}{|c|c|c|c|c|c|c|}
\hline \multicolumn{7}{|c|}{ During the past week, how many TOTAL hours did you ... } \\
\hline \multirow{3}{*}{$\begin{array}{l}\text { 7. Dance (such as square, folk, line, ballroom, } \\
\text { do not count aerobic dance here)? } \\
\square \text { YES How many TIMES a week? } \\
\square \text { NO }\end{array}$} & \multicolumn{6}{|c|}{ How many TOTAL hours a week did you do it? } \\
\hline & \multirow{2}{*}{$\begin{array}{c}\text { Less } \\
\text { than } 1 \\
\text { hour }\end{array}$} & $\begin{array}{l}1-21 / 2 \\
\text { hours }\end{array}$ & \multirow[t]{2}{*}{$\begin{array}{l}3-4 \frac{1}{2} \\
\text { hours }\end{array}$} & \multirow[t]{2}{*}{$\begin{array}{l}5-6^{1 / 2} \\
\text { hours }\end{array}$} & $\begin{array}{l}7-81 / 2 \\
\text { hours }\end{array}$ & $\begin{array}{l}9 \text { or } \\
\text { more }\end{array}$ \\
\hline & & & & & & \\
\hline \multirow{2}{*}{$\begin{array}{l}\text { 9. Play golf, carrying and pulling your } \\
\text { equipment(count walking time only)? } \\
\square \text { YES How many TIMES a week? }\end{array}$} & \multicolumn{6}{|c|}{ How many TOTAL hours a week did you do it? } \\
\hline & $\begin{array}{l}\text { Less } \\
\text { than } 1 \\
\text { hour }\end{array}$ & $\begin{array}{l}1-2 \frac{1}{2} \\
\text { hours }\end{array}$ & $\begin{array}{l}3-4 \frac{1}{2} \\
\text { hours }\end{array}$ & $\begin{array}{l}5-61 / 2 \\
\text { hours }\end{array}$ & $\begin{array}{l}7-81 / 2 \\
\text { hours }\end{array}$ & $\begin{array}{c}9 \text { or } \\
\text { more } \\
\text { hours }\end{array}$ \\
\hline \multirow{3}{*}{$\begin{array}{l}\text { 10. Play golf, riding a cart (count walking } \\
\text { time only)? } \\
\square \text { YES How many TIMES a week? }\end{array}$} & & & & & & \\
\hline & \multicolumn{6}{|c|}{ How many TOTAL hours a week did you do it? } \\
\hline & $\begin{array}{l}\text { Less } \\
\text { than } 1 \\
\text { hour }\end{array}$ & $\begin{array}{l}1-21 / 2 \\
\text { hours }\end{array}$ & $\begin{array}{l}3-41 / 2 \\
\text { hours }\end{array}$ & $\begin{array}{l}5-61 / 2 \\
\text { hours }\end{array}$ & $\begin{array}{l}7-81 / 2 \\
\text { hours }\end{array}$ & $\begin{array}{c}9 \text { or } \\
\text { more } \\
\text { hours }\end{array}$ \\
\hline$\square$ No & & & & & & \\
\hline \multirow{3}{*}{$\begin{array}{l}\text { 14. Play single tennis(do NOT count the } \\
\text { doubles) } \\
\square \text { YES How many TIMES a week? } \\
\square \text { NO }\end{array}$} & \multicolumn{6}{|c|}{ How many TOTAL hours a week did you do it? } \\
\hline & $\begin{array}{l}\text { Less } \\
\text { than } 1 \\
\text { hour }\end{array}$ & $\begin{array}{l}1-21 / 2 \\
\text { hours }\end{array}$ & $\begin{array}{l}3-41 / 2 \\
\text { hours }\end{array}$ & $\begin{array}{l}5-6^{1 / 2} \\
\text { hours }\end{array}$ & $\begin{array}{l}7-81 / 2 \\
\text { hours }\end{array}$ & $\begin{array}{c}9 \text { or } \\
\text { more } \\
\text { hours }\end{array}$ \\
\hline & & & & & & \\
\hline \multirow{2}{*}{ 15. Play double tennis(do $\underline{\text { NOT }}$ count singles) } & \multicolumn{6}{|c|}{ How many TOTAL hours a week did you do it? } \\
\hline & $\begin{array}{l}\text { Less } \\
\text { than } 1\end{array}$ & $\begin{array}{l}1-21 / 2 \\
\text { hours }\end{array}$ & $\begin{array}{l}3-4 \frac{1}{2} \\
\text { hours }\end{array}$ & $\begin{array}{l}5-61 / 2 \\
\text { hours }\end{array}$ & $\begin{array}{l}7-81 / 2 \\
\text { hours }\end{array}$ & $\begin{array}{c}9 \text { or } \\
\text { more } \\
\text { hours }\end{array}$ \\
\hline & & & & & & \\
\hline \multirow[t]{2}{*}{ 16. Skate (ice, roller, in-line)? } & \multicolumn{6}{|c|}{ How many TOTAL hours a week did you do it? } \\
\hline & $\begin{array}{l}\text { Less } \\
\text { than } 1 \\
\text { hour }\end{array}$ & $\begin{array}{l}1-21 / 2 \\
\text { hours }\end{array}$ & $\begin{array}{l}3-4 \frac{1}{2} \\
\text { hours }\end{array}$ & $\begin{array}{l}5-61 / 2 \\
\text { hours }\end{array}$ & $\begin{array}{l}7-81 / 2 \\
\text { hours }\end{array}$ & $\begin{array}{l}9 \text { or } \\
\text { more } \\
\text { hours }\end{array}$ \\
\hline & & & & & & \\
\hline \multirow{2}{*}{$\begin{array}{l}\text { 20. Do light work around the house (such as } \\
\text { sweeping, vacuuming)? } \\
\square \text { YES How many TIMES a week? }\end{array}$} & \multicolumn{6}{|c|}{ How many TOTAL hours a week did you do it? } \\
\hline & $\begin{array}{l}\text { Less } \\
\text { than } 1 \\
\text { hour }\end{array}$ & $\begin{array}{l}1-21 / 2 \\
\text { hours }\end{array}$ & $\begin{array}{l}3-4 \frac{1}{2} \\
\text { hours }\end{array}$ & $\begin{array}{l}5-61 / 2 \\
\text { hours }\end{array}$ & $\begin{array}{l}7-81 / 2 \\
\text { hours }\end{array}$ & $\begin{array}{c}9 \text { or } \\
\text { more } \\
\text { hours }\end{array}$ \\
\hline$\square$ NO & & & & & & \\
\hline \multirow{3}{*}{$\begin{array}{l}\text { 21. Do heavy gardening (such as spading, } \\
\text { raking)? } \\
\square \text { YES How many TIMES a week? } \\
\square \text { NO }\end{array}$} & \multicolumn{6}{|c|}{ How many TOTAL hours a week did you do it? } \\
\hline & $\begin{array}{l}\text { Less } \\
\text { than } 1 \\
\text { hour }\end{array}$ & $\begin{array}{l}1-21 / 2 \\
\text { hours }\end{array}$ & $\begin{array}{l}3-4 \frac{1}{2} \\
\text { hours }\end{array}$ & $\begin{array}{l}5-61 / 2 \\
\text { hours }\end{array}$ & $\begin{array}{l}7-81 / 2 \\
\text { hours }\end{array}$ & $\begin{array}{c}9 \text { or } \\
\text { more } \\
\text { hours }\end{array}$ \\
\hline & & & & & & \\
\hline \multirow{2}{*}{$\begin{array}{l}\text { 22. Do light gardening (such as watering } \\
\text { plants)? } \\
\square \text { YES How many TIMES a week? } \\
\square \text { NO }\end{array}$} & \multicolumn{6}{|c|}{ How many TOTAL hours a week did you do it? } \\
\hline & $\begin{array}{l}\text { Less } \\
\text { than } 1 \\
\text { hour }\end{array}$ & $\begin{array}{l}1-21 / 2 \\
\text { hours }\end{array}$ & $\begin{array}{l}3-41 / 2 \\
\text { hours }\end{array}$ & $\begin{array}{l}5-6^{1 / 2} \\
\text { hours }\end{array}$ & $\begin{array}{l}7-81 / 2 \\
\text { hours }\end{array}$ & $\begin{array}{l}\text { 9or } \\
\text { more } \\
\text { hours }\end{array}$ \\
\hline \multirow{2}{*}{$\begin{array}{l}\text { 23. Work on your car, truck, lawn mower, or } \\
\text { other machinery? } \\
\square \text { YES How many TIMES a week? }\end{array}$} & \multicolumn{6}{|c|}{ How many TOTAL hours a week did you do it? } \\
\hline & $\begin{array}{l}\text { Less } \\
\text { than } 1\end{array}$ & $\begin{array}{l}1-21 / 2 \\
\text { hours }\end{array}$ & $\begin{array}{l}3-4 \frac{1}{2} \\
\text { hours }\end{array}$ & $\begin{array}{l}5-61 / 2 \\
\text { hours }\end{array}$ & $\begin{array}{l}7-81 / 2 \\
\text { hours }\end{array}$ & $\begin{array}{l}9 \text { or } \\
\text { more }\end{array}$ \\
\hline
\end{tabular}




\begin{tabular}{|c|c|c|c|c|c|c|}
\hline \multicolumn{7}{|c|}{ During the past week, how many TOTAL hours did you ... } \\
\hline \multicolumn{7}{|c|}{ * Please note: For the following questions about running and walking, include use of treadmill } \\
\hline \multirow{2}{*}{$\begin{array}{l}\text { 24. Jog or run? } \\
\qquad \begin{array}{l}\square \text { YES How many TIMES a week? } \\
\square \text { NO }\end{array}\end{array}$} & \multicolumn{6}{|c|}{ How many TOTAL hours a week did you do it? } \\
\hline & $\begin{array}{l}\text { Less } \\
\text { than } 1 \\
\text { hour }\end{array}$ & $\begin{array}{l}1-2 \frac{1}{2} \\
\text { hours }\end{array}$ & $\begin{array}{l}3-41 / 2 \\
\text { hours }\end{array}$ & $\begin{array}{l}5-61 / 2 \\
\text { hours }\end{array}$ & $\begin{array}{l}7-81 / 2 \\
\text { hours }\end{array}$ & $\begin{array}{l}9 \text { or } \\
\text { more } \\
\text { hours }\end{array}$ \\
\hline \multirow{2}{*}{$\begin{array}{l}\text { 25. Walk uphill or hike uphill (count uphill } \\
\text { part only)? } \\
\square \text { YES How many TIMES a week? } \\
\square \text { NO }\end{array}$} & \multicolumn{6}{|c|}{ How many TOTAL hours a week did you do it? } \\
\hline & $\begin{array}{l}\text { Hoss } \\
\text { Less } \\
\text { than } 1 \\
\text { hour }\end{array}$ & $\begin{array}{l}1-21 / 2 \\
\text { hours }\end{array}$ & $\begin{array}{l}3-4^{1 / 2} \\
\text { hours }\end{array}$ & $\begin{array}{l}5-61 / 2 \\
\text { hours }\end{array}$ & $\begin{array}{l}7-8^{1 / 2} \\
\text { hours }\end{array}$ & $\begin{array}{l}0 \text { it? } \\
\text { 9 or } \\
\text { more } \\
\text { hours }\end{array}$ \\
\hline \multirow{3}{*}{$\begin{array}{l}\text { 26. Walk fast or briskly for exercise (do not } \\
\text { count walk leisurely or uphill)? } \\
\square \text { YES How many TIMES a week? } \\
\square \text { NO }\end{array}$} & \multicolumn{6}{|c|}{ How many TOTAL hours a week did you do it? } \\
\hline & $\begin{array}{l}\text { Less } \\
\text { than } 1 \\
\text { hour }\end{array}$ & $\begin{array}{l}1-21 / 2 \\
\text { hours }\end{array}$ & $\begin{array}{l}3-41 / 2 \\
\text { hours }\end{array}$ & $\begin{array}{l}5-6^{1 / 2} \\
\text { hours }\end{array}$ & $\begin{array}{l}7-81 / 2 \\
\text { hours }\end{array}$ & $\begin{array}{l}9 \text { or } \\
\text { more } \\
\text { hours }\end{array}$ \\
\hline & & & & & & \\
\hline \multirow{2}{*}{$\begin{array}{l}\text { 27. Walk to do errands (such as to/from store } \\
\text { or take children to school, count walk time } \\
\text { only)? } \\
\square \text { YES How many TIMES a week? }\end{array}$} & \multicolumn{6}{|c|}{ How many TOTAL hours a week did you do it? } \\
\hline & $\begin{array}{c}\text { Less } \\
\text { than } 1 \\
\text { hour }\end{array}$ & $\begin{array}{l}1-2 \frac{1}{2} \\
\text { hours }\end{array}$ & $\begin{array}{l}3-4 \frac{1}{2} 2 \\
\text { hours }\end{array}$ & $\begin{array}{l}5-6^{1 / 2} \\
\text { hours }\end{array}$ & $\begin{array}{l}7-81 / 2 \\
\text { hours }\end{array}$ & $\begin{array}{c}9 \text { or } \\
\text { more } \\
\text { hours }\end{array}$ \\
\hline & & & & & & \\
\hline \multirow{2}{*}{ 28. Walk leisurely for exercise or pleasure? } & \multicolumn{6}{|c|}{ How many TOTAL hours a week did you do it? } \\
\hline & $\begin{array}{l}\text { Less } \\
\text { than } 1 \\
\text { hour }\end{array}$ & $\begin{array}{l}1-2 \frac{1}{2} \\
\text { hours }\end{array}$ & $\begin{array}{l}3-4 \frac{1}{2} \\
\text { hours }\end{array}$ & $\begin{array}{l}5-6^{1 / 2} \\
\text { hours }\end{array}$ & $\begin{array}{l}7-81 / 2 \\
\text { hours }\end{array}$ & $\begin{array}{l}9 \text { or } \\
\text { more } \\
\text { hours }\end{array}$ \\
\hline & & & & & & \\
\hline \multirow{2}{*}{ 29. Ride a bicycle or stationary cycle? } & \multicolumn{6}{|c|}{ How many TOTAL hours a week did you do it? } \\
\hline & $\begin{array}{l}\text { Less } \\
\text { than } 1 \\
\text { hour }\end{array}$ & $\begin{array}{l}1-21 / 2 \\
\text { hours }\end{array}$ & $\begin{array}{l}3-41 / 2 \\
\text { hours }\end{array}$ & $\begin{array}{l}5-6^{1 / 2} \\
\text { hours }\end{array}$ & $\begin{array}{l}7-81 / 2 \\
\text { hours }\end{array}$ & $\begin{array}{l}9 \text { or } \\
\text { more } \\
\text { hours }\end{array}$ \\
\hline & & & & & & \\
\hline \multirow{2}{*}{$\begin{array}{l}\text { 30. Do other aerobic machine such as rowing } \\
\text { or stepping machines (do not count treadmill } \\
\text { or stationary cycle? } \\
\square \text { YES How many TIMES a week? }\end{array}$} & \multicolumn{6}{|c|}{ How many TOTAL hours a week did you do it? } \\
\hline & $\begin{array}{c}\text { Less } \\
\text { than } 1 \\
\text { hour }\end{array}$ & $\begin{array}{l}1-21 / 2 \\
\text { hours }\end{array}$ & $\begin{array}{l}3-4^{1 / 2} \\
\text { hours }\end{array}$ & $\begin{array}{l}5-61 / 2 \\
\text { hours }\end{array}$ & $\begin{array}{l}7-81 / 2 \\
\text { hours }\end{array}$ & $\begin{array}{l}9 \text { or } \\
\text { more } \\
\text { hours }\end{array}$ \\
\hline$\square$ No & & & & & & \\
\hline \multirow{3}{*}{$\begin{array}{l}\text { 31. Do water exercises (do not count other } \\
\text { swimming)? } \\
\square \text { YES How many TIMES a week? } \\
\square \text { NO }\end{array}$} & \multicolumn{6}{|c|}{ How many TOTAL hours a week did you do it? } \\
\hline & $\begin{array}{l}\text { Less } \\
\text { than } 1 \\
\text { hour }\end{array}$ & $\begin{array}{l}1-21 / 2 \\
\text { hours }\end{array}$ & $\begin{array}{l}3-41 / 2 \\
\text { hours }\end{array}$ & $\begin{array}{l}5-6^{1 / 2} \\
\text { hours }\end{array}$ & $\begin{array}{l}7-81 / 2 \\
\text { hours }\end{array}$ & $\begin{array}{l}9 \text { or } \\
\text { more } \\
\text { hours }\end{array}$ \\
\hline & & & & & & \\
\hline \multirow[t]{2}{*}{ 32. Swim moderately or fast? } & \multicolumn{6}{|c|}{ How many TOTAL hours a week did you do it? } \\
\hline & $\begin{array}{l}\text { Less } \\
\text { than } 1 \\
\text { hour }\end{array}$ & $\begin{array}{l}1-21 / 2 \\
\text { hours }\end{array}$ & $\begin{array}{l}3-4 \frac{1}{2} \\
\text { hours }\end{array}$ & $\begin{array}{l}5-61 / 2 \\
\text { hours }\end{array}$ & $\begin{array}{l}7-81 / 2 \\
\text { hours }\end{array}$ & $\begin{array}{l}9 \text { or } \\
\text { more } \\
\text { hours }\end{array}$ \\
\hline$\square$ No & & & & & & \\
\hline \multirow{2}{*}{$\begin{array}{l}\text { 33. Swim gently? } \\
\square \text { YES How many TIMES a week? } \\
\square \text { NO }\end{array}$} & \multicolumn{6}{|c|}{ How many TOTAL hours a week did you do it? } \\
\hline & $\begin{array}{l}\text { Less } \\
\text { than } 1 \\
\text { hour }\end{array}$ & $\begin{array}{l}1-21 / 2 \\
\text { hours }\end{array}$ & $\begin{array}{l}3-41 / 2 \\
\text { hours }\end{array}$ & $\begin{array}{l}5-61 / 2 \\
\text { hours }\end{array}$ & $\begin{array}{l}7-81 / 2 \\
\text { hours }\end{array}$ & $\begin{array}{l}9 \text { or } \\
\text { more } \\
\text { hours }\end{array}$ \\
\hline
\end{tabular}




\begin{tabular}{|c|c|c|c|c|c|c|}
\hline \multicolumn{7}{|c|}{ During the past week, how many TOTAL hours did you ... } \\
\hline \multirow{3}{*}{$\begin{array}{l}\text { 34. Do stretching or flexibility exercises (do } \\
\text { not count yoga or tai-chi)? } \\
\square \text { YES How many TIMES a week? } \\
\square \text { NO }\end{array}$} & \multicolumn{6}{|c|}{ How many TOTAL hours a week did you do it? } \\
\hline & \multirow{2}{*}{$\begin{array}{l}\text { Less } \\
\text { than } 1 \\
\text { hour }\end{array}$} & \multirow[t]{2}{*}{$\begin{array}{l}1-2 \frac{1}{2} \\
\text { hours }\end{array}$} & $\begin{array}{l}3-4 \frac{1}{2} \\
\text { hours }\end{array}$ & $\begin{array}{l}5-61 / 2 \\
\text { hours }\end{array}$ & $\begin{array}{l}7-81 / 2 \\
\text { hours }\end{array}$ & \multirow[t]{2}{*}{$\begin{array}{c}9 \text { or } \\
\text { more } \\
\text { hours }\end{array}$} \\
\hline & & & & & & \\
\hline \multirow{3}{*}{$\begin{array}{l}\text { 35. Do Yoga or Tai-chi? } \\
\qquad \text { YES How many TIMES a week? } \\
\square \text { NO }\end{array}$} & \multicolumn{6}{|c|}{ How many TOTAL hours a week did you do it? } \\
\hline & \multirow[t]{2}{*}{$\begin{array}{l}\text { Less } \\
\text { than } 1 \\
\text { hour }\end{array}$} & \multirow[t]{2}{*}{$\begin{array}{l}1-2 \frac{1}{2} \\
\text { hours }\end{array}$} & \multirow[t]{2}{*}{$\begin{array}{l}3-41 / 2 \\
\text { hours }\end{array}$} & $\begin{array}{l}5-61 / 2 \\
\text { hours }\end{array}$ & $\begin{array}{l}7-81 / 2 \\
\text { hours }\end{array}$ & $\begin{array}{l}9 \text { or } \\
\text { more } \\
\text { hours }\end{array}$ \\
\hline & & & & & & \\
\hline \multirow[t]{2}{*}{ 36. Do aerobics or aerobic dancing? } & \multicolumn{6}{|c|}{ How many TOTAL hours a week did you do it? } \\
\hline & $\begin{array}{c}\text { Less } \\
\text { than } 1 \\
\text { hour }\end{array}$ & $\begin{array}{l}1-2 \frac{1}{2} \\
\text { hours }\end{array}$ & $\begin{array}{l}\text { 3-4 } 1 / 2 \\
\text { hours }\end{array}$ & $\begin{array}{l}-61 / 2 \\
\text { hours }\end{array}$ & $\begin{array}{l}7-81 / 2 \\
\text { hours }\end{array}$ & $\begin{array}{c}9 \text { or } \\
\text { more } \\
\text { hours }\end{array}$ \\
\hline & & & & & & \\
\hline \multirow{3}{*}{$\begin{array}{l}\text { 37. Do moderate to heavy strength training } \\
\text { (such as hand-held weights of more than } 5 \\
\text { lbs., weight machines, or push-ups? } \\
\square \text { YES How many TIMES a week? } \\
\square \text { NO }\end{array}$} & \multicolumn{6}{|c|}{ How many TOTAL hours a week did you do it? } \\
\hline & \begin{tabular}{c|} 
Less \\
than 1 \\
hour
\end{tabular} & $\begin{array}{l}1-2 \frac{1}{2} \\
\text { hours }\end{array}$ & $\begin{array}{l}3-41 / 2 \\
\text { hours }\end{array}$ & $\begin{array}{l}5-61 / 2 \\
\text { hours }\end{array}$ & $\begin{array}{l}7-81 / 2 \\
\text { hours }\end{array}$ & $\begin{array}{l}9 \text { or } \\
\text { more } \\
\text { hours } \\
\end{array}$ \\
\hline & & & & & & \\
\hline \multirow{2}{*}{$\begin{array}{l}\text { 38. Do light strength training (such as hand- } \\
\text { held weights of } 5 \text { lbs. or less or elastic bands? }\end{array}$} & \multicolumn{6}{|c|}{ How many TOTAL hours a week did you do it? } \\
\hline & $\begin{array}{c}\text { Less } \\
\text { than } 1 \\
\text { hour }\end{array}$ & $\begin{array}{l}1-2 \frac{1 / 2}{2} \\
\text { hours }\end{array}$ & $\begin{array}{l}3-4 \frac{1}{2} \\
\text { hours }\end{array}$ & $\begin{array}{l}5-6 \frac{1}{2} \\
\text { hours }\end{array}$ & $\begin{array}{l}7-8 \frac{1}{2} \\
\text { hours }\end{array}$ & $\begin{array}{c}9 \text { or } \\
\text { more } \\
\text { hours }\end{array}$ \\
\hline$\square$ NO & & & & & & \\
\hline \multirow{3}{*}{$\begin{array}{l}\text { 39. Do general conditioning exercises, such as } \\
\text { light calisthetics or chain exercises(do not } \\
\text { count strength training)? } \\
\square \text { YES How many TIMES a week? } \\
\square \text { No }\end{array}$} & \multicolumn{6}{|c|}{ How many TOTAL hours a week did you do it? } \\
\hline & $\begin{array}{c}\text { Less } \\
\text { than } 1 \\
\text { hour }\end{array}$ & $\begin{array}{l}1-2 \frac{1}{2} \\
\text { hours }\end{array}$ & $\begin{array}{l}3-4 \frac{1}{2} \\
\text { hours }\end{array}$ & $\begin{array}{l}5-6 \frac{1}{2} \\
\text { hours }\end{array}$ & $\begin{array}{l}7-81 / 2 \\
\text { hours }\end{array}$ & $\begin{array}{c}9 \text { or } \\
\text { more } \\
\text { hours }\end{array}$ \\
\hline & & & & & & \\
\hline \multirow{2}{*}{$\begin{array}{l}\text { 40. Play basketball, soccer, or racquetball (do } \\
\text { not count time on sidelines)? } \\
\square \text { YES How many TIMES a week? }\end{array}$} & \multicolumn{6}{|c|}{ How many TOTAL hours a week did you do it? } \\
\hline & $\begin{array}{l}\text { Less } \\
\text { than } 1 \\
\text { hour }\end{array}$ & $\begin{array}{l}1-2 \frac{1}{2} \\
\text { hours }\end{array}$ & $\begin{array}{l}3-41 / 2 \\
\text { hours }\end{array}$ & $\begin{array}{l}5-61 / 2 \\
\text { hours }\end{array}$ & $\begin{array}{l}7-81 / 2 \\
\text { hours }\end{array}$ & $\begin{array}{l}9 \text { or } \\
\text { more } \\
\text { hours }\end{array}$ \\
\hline 41. Do other types of physical activity not & How & many $\mathbf{T}$ & TAL ho & rs a wee & did you & o it? \\
\hline previously mentioned(please specify)? & $\begin{array}{c}\text { Less } \\
\text { than } 1 \\
\text { hour }\end{array}$ & $\begin{array}{l}1-2 \frac{1}{2} \\
\text { hours }\end{array}$ & $\begin{array}{l}3-4 \frac{1}{2} \\
\text { hours }\end{array}$ & $\begin{array}{l}5-61 / 2 \\
\text { hours }\end{array}$ & $\begin{array}{l}7-81 / 2 \\
\text { hours }\end{array}$ & $\begin{array}{c}9 \text { or } \\
\text { more } \\
\text { hours }\end{array}$ \\
\hline
\end{tabular}




\section{Appendix C: Research Instruments - HADS Questionnaire}

Hospital Anxiety and Depression Scale (HADS)

Patients are asked to choose one response from the four given for each interview. They should give an immediate response and be dissuaded

from thinking too long about their answers. The questions relating to

anxiety are marked "A", and to depression "D". The score for each answer

is given in the right column. Instruct the patient to answer how it currently describes their feelings.

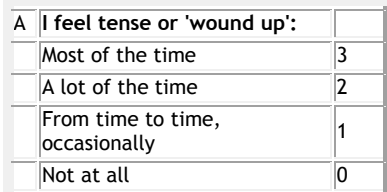

D I still enjoy the things I used to enjoy:

Definitely as much

Not quite so much $\quad 1$

Only a little 2

Hardly at all

I get a sort of frightened

feeling as if something awful

is about to happen:

Very definitely and quite

badly

Yes, but not too badly

me but it doesn't worry

Not at all

0 
D I can laugh and see the funny side of things:

\begin{tabular}{|l|l|}
\hline As much as I always could & 0 \\
\hline Not quite so much now & 1 \\
\hline Definitely not so much now & 2 \\
\hline Not at all & 3 \\
\hline
\end{tabular}

\begin{tabular}{|c|c|c|}
\hline A & $\begin{array}{l}\text { Worrying thoughts go } \\
\text { through my mind: }\end{array}$ & \\
\hline & A great deal of the time & 3 \\
\hline & A lot of the time & 2 \\
\hline & $\begin{array}{l}\text { From time to time, but not } \\
\text { too often }\end{array}$ & 1 \\
\hline & Only occasionally & 0 \\
\hline
\end{tabular}

\begin{tabular}{|l|l|}
\hline D & \\
\hline I feel cheerful: & 3 \\
\hline Not at all & 2 \\
\hline Not often & 1 \\
\hline Sometimes & 0 \\
\hline Most of the time & \\
\hline
\end{tabular}

\begin{tabular}{|l|l|}
\hline $\begin{array}{l}\text { I can sit at ease and feel } \\
\text { relaxed: }\end{array}$ & \\
\hline Definitely & 0 \\
\hline Usually & 1 \\
\hline Not Often & 2 \\
\hline Not at all & 3 \\
\hline
\end{tabular}




\begin{tabular}{|l|l|}
\hline D I feel as if I am slowed down: & \\
\hline Nearly all the time & 3 \\
\hline Very often & 2 \\
\hline Sometimes & 1 \\
\hline Not at all & 0 \\
\hline
\end{tabular}

\begin{tabular}{|l|l|}
\hline $\begin{array}{l}\text { I get a sort of frightened } \\
\text { feeling like 'butterflies' in } \\
\text { the stomach: }\end{array}$ & \\
\hline Not at all & 0 \\
\hline Occasionally & 1 \\
\hline Quite Often & 2 \\
\hline Very Often & 3 \\
\hline
\end{tabular}

D I have lost interest in my appearance: Definitely

I don't take as much care as I should

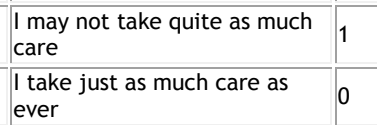

ever

\begin{tabular}{|l|l|}
\hline A I feel restless as I have to be & \\
on the move: & \\
\hline Very much indeed & 3 \\
\hline Quite a lot & 2 \\
\hline
\end{tabular}




\begin{tabular}{|l|l|}
\hline Not very much & 1 \\
\hline Not at all & 0 \\
\hline
\end{tabular}

\begin{tabular}{|c|c|c|}
\hline ) & $\begin{array}{l}\text { I look forward with } \\
\text { enjoyment to things: }\end{array}$ & \\
\hline & As much as I ever did & 0 \\
\hline & Rather less than I used to & 1 \\
\hline & Definitely less than I used to & 2 \\
\hline & Hardly at all & 3 \\
\hline
\end{tabular}

\begin{tabular}{l|l|l|}
\hline A & $\begin{array}{l}\text { I get sudden feelings of } \\
\text { panic: }\end{array}$ \\
\hline Very often indeed & 3 \\
\hline Quite often & 2 \\
\hline Not very often & 1 \\
\hline Not at all & 0 \\
\hline
\end{tabular}

D I can enjoy a good book or radio or TV program:

\begin{tabular}{|l|l|}
\hline Often & 0 \\
\hline Sometimes & 1 \\
\hline Not often & 2 \\
\hline Very seldom & 3 \\
\hline
\end{tabular}

